\title{
A FAMÍLIA ERIOCAULACEAE NO PARQUE ESTADUAL DO IBITIPOCA, MINAS GERAIS, BRASIL
}

\author{
CAROLINA SARQUIS AIEX MARINI FERREIRA*, MARCELO TROVÓ** \& \\ RAFAELA CAMPOSTRINI FORZZA*
}

\author{
* Jardim Botânico do Rio de Janeiro, Rua Pacheco Leão 915, \\ 22460-30 - Rio de Janeiro, RJ, Brasil (e-mail: rafaela@jbrj.gov.br) \\ ** Departamento de Botânica, Instituto de Biociências, Universidade de São Paulo, \\ Rua do Matão, 277, 05508-900 - São Paulo, SP, Brasil (e-mail: martrovo@gmail.com).
}

\begin{abstract}
Eriocaulaceae in the Ibitipoca State Park, Minas Gerais, Brazil). In Brazil, Eriocaulaceae comprise ca. 600 species and nine genera. Most of the taxonomic and morphological diversity center is concentrated in the campos rupestres from the Espinhaço Range. The Ibitipoca State Park (PEIB) is located within the Mantiqueira complex and is composed of different vegetation types. The present study is the floristic treatment of Eriocaulaceae species occurring in the PEIB. Twenty-two species were found, sixteen of Paepalanthus, two of Comanthera, two of Syngonanthus, one of Leiothrix, and one of Eriocaulon. These species occur in various habitats, but are frequently found in open grass dominated formations. An identification key, line drawings, descriptions, besides comments on morphological variation and geographical distribution are provided. Two new synonyms are proposed: Paepalanthus ibitipocencis Silveira $=P$. calvus Körn. e Paepalanthus orthoblepharus Silveira $=P$. henriquei Silveira \& Ruhland
\end{abstract}

Key words: campo rupestre, Atlantic Forest, flora, taxonomy.

\begin{abstract}
Resumo - (Eriocaulaceae no Parque Estadual do Ibitipoca, Minas Gerais, Brasil). No Brasil, Eriocaulaceae compreende cerca de 600 espécies e nove gêneros. O principal centro de diversidade da família está nos campos rupestres da Cadeia do Espinhaço. Adjacente a este centro, o Parque Estadual do Ibitipoca (PEIB) está inserido no complexo da Mantiqueira e é formado por um mosaico de formações campestres e florestais. O trabalho aqui apresentado traz o tratamento taxonômico das Eriocaulaceae ocorrentes no PEIB. Foram registradas 22 espécies, sendo 16 de Paepalanthus, duas de Comanthera, duas de Syngonanthus, uma de Leiothrix e uma de Eriocaulon. As espécies ocorrem em diversos ambientes, porém são mais frequentes nas áreas campestres. São apresentadas ilustrações, descrições, chave de identificação e comentários sobre variação morfológica e distribuição geográfica dos táxons. São apresentados dois novos sinônimos: Paepalanthus ibitipocencis Silveira $=P$. calvus Körn. e Paepalanthus orthoblepharus Silveira $=P$. henriquei Silveira \& Ruhland.
\end{abstract}

Palavras-chave: campo rupestre, Mata Atlântica, flora, taxonomia.

\section{Introdução}

Eriocaulaceae compreende cerca de 1.200 espécies, distribuídas em 11 gêneros e é caracterizada pelas inflorescências em capítulo portando flores geralmente unissexuais (Ruhland 1903, Koernicke 1863, Stützel 1998). É tradicionalmente dividida em duas subfamílias: Eriocauloideae e Paepalanthoideae (Ruhland 1903). A primeira é caracterizada por possuir androceu diplostêmone e pétalas com glândulas, enquanto a segunda possui androceu isostêmone e pétalas sem glândulas (Koernicke 1863, Ruhland 1903, Stützel 1998). Apresenta distribuição pantropical e elevado número de endemismos (Ruhland 1903, Giulietti \& Hensold 1990, Giulietti et al. 2005). No Brasil, são encontradas cerca de 700 espécies distribuídas em nove gêneros: Actinocephalus (30 espécies), Comanthera (37), Eriocaulon (55), Leiothrix (49), Paepalanthus (357), Philodice (2), Rondonanthus (3), Syngonanthus (90) e Tonina (1) (Giulietti et al. 2010).
O principal centro de diversidade de Eriocaulaceae localiza-se na Cadeia do Espinhaço, em Minas Gerais e Bahia (Giulietti \& Hensold 1990, Stützel 1998). Levantamentos florísticos realizados nestas áreas indicam Eriocaulaceae como uma das famílias com maior riqueza, especialmente nos campos rupestres. No Pico das Almas (BA), foram registradas 27 espécies reunidas em quatro gêneros (Giulietti \& Parra 1995); em Mucugê (BA), ocorem 32 espécies e quatro gêneros (Harley \& Simmons 1986); no Morro do Pai Inácio e Serra da Chapadinha (BA), 18 espécies e cinco gêneros (Miranda \& Giulietti 2001); em Catolés (BA), 55 espécies e seis gêneros (Giulietti et al. 2003); na Serra do Cipó (MG), 87 espécies distribuídas e cinco gêneros (Giulietti \& Hensold 1987); e em Grão-Mogol (MG), 33 espécies e cinco gêneros (Sano et al. 2010).

O Parque Estadua do Ibitipoca, foi classificado por Costa et al. (1998) na categoria de "Extrema Importância Biológica", em razão de sua fauna e flora, além de sua singularidade espeleológica e diversidade 
de habitats. Drummond et al. (2005) citaram a Serra do Ibitipoca como área prioritária para a conservação da flora de Minas Gerais, na categoria "Importância Biológica Especial". O turismo é apontado como a maior pressão antrópica sobre a área, devido principalmente à fragilidade dos solos e à distribuição restrita de determinadas espécies de plantas e líquens (Costa et al. 1998).

Se por um lado, para as serras da Cadeia do Espinhaço varios estudos já foram publicados enfocando Eriocaulaceae, por outro as vegetações campestres do Domínio Atlântico carecem de monografias que trataem da família. Assim, o presente trabalho tem por objetivo apresentar 0 estudo taxonômico das Eriocaulaceae do Parque Estadual do Ibitipoca, uma área disjunta do centro de diversidade da família e enserida no Domínio Atlântico, contribuindo para o melhor entendimento das espécies e ampliando o conhecimento das formações campestres de altitude do Brasil.

\section{Material e métodos}

A Serra de lbitipoca está situada no sudeste de Minas Gerais e faz parte do Complexo da Mantiqueira, com relevo caracterizado pelas escarpas altas entre 1.200-1.800 m de altitude. O clima na região é do tipo Cwb, mesotérmico úmido, com verões amenos e invernos secos, precipitação média anual de $1.532 \mathrm{~mm}$ e temperatura média de $18,9^{\circ} \mathrm{C}$ (CETEC 1983). O Parque Estadual do Ibitipoca (PEIB) representa uma área de 1.488 ha. da Serra e inclui trechos dos municípios de Santa Rita de Ibitipoca e Lima Duarte, entre as coordenadas $21^{\circ} 40^{\prime}-21^{\circ} 44^{\prime} \mathrm{S}$ e $43^{\circ} 52^{\prime}-43^{\circ} 55^{\prime} \mathrm{W}$. Diversas propostas de denominação para os tipos vegetacionais ocorrentes no Parque foram apresentadas por distintos autores, não havendo um consenso entre os mesmos. Acreditamos que as denominações mais adequadas às fisionomias do Parque são as propostas de Andrade \& Sousa (1995), para os campos, e de Fontes (1997) para as florestas. Para maiores detalhes sobre o Parque ver Menini Neto et al. (2007a, b).

O levantamento das espécies presentes no PEIB foi realizado através de revisão bibliográfica, visitas a herbários e expedições de coleta. Foram examinadas as coleções dos herbários B, CESJ, RB, R, SPF e SP. As descrições foram elaboradas utilizando-se as ter- minologias propostas por Radford (1976) e Font Quer (1989). É apresentada uma chave de identificação para as espécies, descrições, comentários e ilustrações para cada espécie.

\section{Resultados e discussão}

No presente estudo foram registradas 22 espécies de Eriocaulaceae no PEIB, distribuídas em cinco gêneros. Paepalanthus é o mais diverso, com 16 táxons, seguido por Comanthera e Syngonanthus com duas espécies cada e Eriocaulon e Leiothrix, com apenas uma cada. Além dos táxons aqui apresentados, Giulietti (1984) referiu para a Serra do Ibitipoca Leiothrix beckii Ruhland (M. Magalhães 1366). Entretanto, este espécimem não foi localizado nos herbários consultados e novos exemplares não foram encontrados durante as coletas realizadas. Silveira (1928) redescreveu Syngonanthus crispus Silveira (= Comanthera bisulcata (Köern.) L.R.Parra \& Giul.) com base no material $M$. Magalhães 225, coletado na Serra do Ibitipoca. Parra et al. (2010) relatam que tal material encontra-se em um envelope depostitado em no herbário $\mathrm{R}$ e está mesclado com outro espécime ( $A$. Silveira 225) coletado na Serra do Cabral. Tal envelope, contendo ambas coletas, não foi localizado no herbário $R$ e novos exemplares desta espécie não foram encontrados no PEIB.

O Parque Estadual do Ibitipoca encontra-se isolado em uma área do Domínio da Floresta Atlântica, apresentando um elevado número de espécies endêmicas (Rodela 1998, Salimena 2000). Para Eriocaulaceae, foram registradas seis espécies conhecidas apenas do Parque. Chama atenção o número de táxons restritos ao Domínio Atlântico (Paepalanthus calvus, P. macaheensis, P. dupatya, $P$. harmsii e $P$. leiseringii), enquanto apenas $P$. freyreissii e $P$. planifolius ocorrem disjuntamente no Espinhaço e na Serra da Mantiqueira. Estes números corroboram autores anteriores (Menini Neto et al. 2007a, Ferreira et al. 2009, Borges et al. 2010) que demonstraram que a flora da Serra do Ibitipoca é mais similar a outras áreas de altitude do Domínio Atlântico do que com a flora da Cadeia do Espinhaço. Porém, infelizmente, não existem levantamos mais acurados para a família em áreas de campos de altitude da Floresta Atlântica para que esta comparação seja feita com mais precisão.

Chave para identificação das espécies de Eriocaulaceae ocorrentes no PEIB

1. Folhas fenestradas na base; flores diplostêmones, pétalas com glândulas negras na face adaxial ....... Eriocaulon vaginatum

1'. Folhas não fenestradas na base, flores isostêmones, pétalas sem glândulas.

2. Flores pistiladas com ramos estigmáticos e ramos nectaríferos liberando-se em alturas diferentes; anteras basifixas Leiothrix flavescens

2'. Flores pistiladas com ramos estigmáticos e ramos nectaríferos liberando-se na mesma altura; anteras dorsifixas.

3. Pétalas das flores pistiladas livres Paepalanthus

4. Escapos fundidos.

5. Folhas lineares $(0,4-0,7 \mathrm{~cm}$ larg. $)$, pilosas em ambas as faces P. dupatya 
5'. Folhas lanceoladas $(0,8-2,0 \mathrm{~cm}$ larg. $)$, pilosas somente na face abaxial P. planifolius 4'. Escapos livres.

6. Brácteas involucrais externas ultrapassando o diâmentro do capítulo.

7. Ápice da folha agudo, brácteas involucrais castanho-escuras, brácteas florais castranho escuras, anteras castanhas

7'. Ápice da folha acuminado, brácteas involucrais estramíneas, brácteas florais castanho claras, anteras alvas a creme.

8. Folhas lineares, hirsutas, 3-6 mm larg.

8'. Folhas lanceoladas, glabrescentes, 7-27 mm larg.

P. leiseringii

Brácteas involucrais externas não ultrapassando o diâm

9. Flores dímeras.

10. Planta com 41-59 cm alt., capítulos discóides

10'. Planta com 2,1-9,3 cm alt.; capítulos semiglobosos

9'. Flores trímeras.

11. Capítulos vivíparos.

12. Caule alongado, folhas lanceoladas, $10-23 \times 1-3 \mathrm{~mm}$.

12. Caule restrito à roseta, folhas lineares, $3-6 \times 0,5-10 \mathrm{~mm}$

11'. Capítulos não vivíparos.

13. Folhas dispostas em roseta.

14. Escapos do mesmo tamanho das folhas

14'. Escapos distintamente maiores que as folhas, espatas $5-11 \mathrm{~cm}$.

15. Folhas $0,8-2 \times 0,05-0,1 \mathrm{~cm}$, brácteas involucrais castanho-claras .................. P. miser

15'. Folhas 4,0-10 X 0,4-0,9 cm brácteas involucrais castanho escuras.

16. Espatas 5-11 cm compr., capítulo 0,7-1,0 cm diam. ............................... P. calvus

16 . Espatas 1,5-4 cm compr., capítulo 0,3-0,6 cm diam.................................. euryphyllus

13'. Folhas dispostas ao longo de um caule alongado.

17. Folhas lanceoladas, espatas $2,5-4,0 \mathrm{~cm}$ compr ................................... P. macaheensis

17'. Folhas lineares, espatas $0,6-2,1 \mathrm{~cm}$ compr.

18. Folhas $0,3-0,5 \mathrm{~mm}$ larg., pilosas, brácteas involucrais pardas ....

P. manicatus

18'. Folhas 0,5-2 mm larg., glabrescentes, brácteas involucrais castanho-escuras

P. freyreissii

3'. Pétalas das flores pistiladas fundidas na porção mediana.

19. Pétalas da flor pistilada superando as sépalas; brácteas involucrais superando o capítulo

20. Lâmina foliar linear, densamente ciliada.

20'. Lâmina foliar cilíndrica, esparsamente ciliada ........................................................

Comanthera

superando o capítulo

21. Folhas 0,5-1 mm larg., pilosas, ápice acuminado, capítulos 3-6 mm diâm.

21'. Folhas 1-2 mm larg., glabrescentes, ápice agudo, capítulos 6-9 mm diâm

C. linearis

C. nivea

Syngonanthus S. Nitens

\section{Comanthera L.B.Sm.}

Ervas, terrestres, perenes ou anuais, caule restrito à roseta. Folhas em roseta basal, espiraladas; lineares a oblongas, hirsutas a glabras, bainha alargada, persistentes ou não, não fenestradas. Flores 3-meras, isostêmones, sem glândulas nas pétalas. Brácteas florais ausentes. Flores estaminadas pediceladas, sépalas unidas na base ou até a região mediana, pétalas unidas até a região mediana, anteras bitecas, tetraesporangiadas, alvas, dorsifixas; pistilódios presentes, antóforo presente. Flores pistiladas pediceladas ou sésseis, sépalas livres, pétalas maiores que as sépalas, unidas apenas na região mediana, ovário 3-locular ramos estigmáticos simples, partindo da mesma altura dos ramos nectaríferos.

Comanthera é um gênero de distribuição restrita à América do Sul, abrangendo 38 espécies, geralmente encontradas em solos quartzíticos, arenosos ou rochosos. Muitas espécies do gênero apresentam importância econômica, por serem extraídas e vendidas como "sempre-vivas" (Parra et al. 2010). No PEIB está representado por duas espécies.
1.1. Comanthera linearis (Ruhland) L.R. Parra \& Giul., Taxon 59: 1141. 2010.

Fig.1. A-C.

Planta $15-27 \mathrm{~cm}$ alt. Rizoma presente ou não. Caule aéreo reduzido, ca. $0,2 \mathrm{~cm}$ compr. Folhas dispostas em roseta, lineares, 2,4-6 X 0,1-0,2 cm, glabras, densamente ciliadas, ápice obtuso. Espatas 2,7$4 \mathrm{~cm}$ compr., hirsutas, fendidas obliquamente, estriadas, ápice não dilatado. Escapos 6-24,5 cm compr., hirsutos, tricostados, livres. Capítulos semiglobosos, 4-10 mm diâm., não vivíparos; brácteas involucrais superando 0 capítulo, douradas, ápice hialino, dispostas em 4-5 séries, oblanceoladas, glabras, ápice obtuso. Brácteas florais ausentes. Flores estaminadas ca. $2 \mathrm{~mm}$ compr., pedicelo ca. $1 \mathrm{~mm}$, glabro, amarelado; sépalas hialinas, obovais, glabras, ápice agudo; pétalas hialinas, obovais, glabras, ápice agudo; pistilódios 3 , papilosos. Flores pistiladas ca. $3 \mathrm{~mm}$ compr.; sépalas hialinas, obovais, glabras, ápice acuminado; pétalas hialinas, lineares, vilosas do centro à base, ápice obtuso; ramos estigmáticos simples, 3 vezes mais longos que os ramos nectaríferos. 
Material selecionado: s.I., 1.XI.1973, U.C. Câmara 154 (CESJ, RB, SPF); s.l., 16.III.1977, L. Krieger s.n. (CESJ 15257, RB, SPF); trecho entre a praia do Ribeirão e a Ponte de Pedra, 30.IX.1970, D. Sucre et al. 7236 (RB); Janela do Céu, 20.IX.2006, R.C. Forzza et al. 4265 (CESJ, K, RB, SPF); trilha entre Lombada e Cruzeiro, 19.IX.2007, C. Sarquis et al. 16 (NY, RB); trilha para Cachoeirinha, 31.III.2004, C. Morato et al. 23 (RB).

Comanthera linearis possui distribuição disjunta entre os campos rupestres de Ibitipoca e as áreas de restinga do Rio de Janeiro e Espírito Santo. No PEIB, é encontrada com frequência em solos arenosos. Facilmente distinta das demais espécies de Comanthera pela folha com margem densamente ciliada.

1.2. Comanthera nivea (Bong.) L.R. Parra \& Giul., Taxon 59: 1141. 2010.

Fig.1. D-F.

Planta 11-30 cm alt. Rizoma ausente. Caule aéreo ca. 0,5 cm compr. Folhas dispostas em roseta basal, cilíndricas, 1,5-4 $\times$ 0,05-0,1 cm, pilosas, esparsamente ciliadas, ápice agudo. Espatas 2,3-4,4 cm compr. glabrescentes, fendidas obliquamente, estriadas, ápice não-dilatado. Escapos 5,3-30 cm compr., hirsutos a glabrescentes, multicostados, livres. Capítulos semiglobosos, 3-6 mm diâm., não vivíparos; brácteas involucrais superando o capítulo, alvas, base dourada, dispostas em 3 séries, oblanceoladas, pilosas na base, ápice obtuso. Brácteas florais hialinas, oblanceoladas, glabras, ápice agudo. Flores estaminadas ca. $2 \mathrm{~mm}$ compr., pedicelo ca. $1 \mathrm{~mm}$ compr., viloso na base; sépalas hialinas, obovais, glabras, ápice obtuso; tubo da corola hialino; pistilódios 3, pilosos. Flores pistiladas ca. 2 $\mathrm{mm}$ compr.; sépalas hialinas, obovais, glabras, ápice obtuso; pétalas hialinas, lineares, glabras, ápice agudo; ramos estigmáticos simples, mais curtos que as os ramos nectaríferos.

Material selecionado: s.I., 3.XI.1973, U.C. Câmara 161 (CESJ, RB, SPF); Lagoa Seca, 10.II.2001, R.C. Forzza et al. 1835 (CESJ, RB, SPF); margem da estrada em direção à Janela do Céu, 5.II.2004, B.R. Silva et al. 1272 (CESJ, K, MBM, NY, RB, SPF); trilha Monjolinho-Lagoa Seca, 30.III.2004, C. Morato et al. 20 (HUEFS, RB); trilha entre Lombada e Cruzeiro, 19.IX.2007, C. Sarquis et al. 15 (RB).

Comanthera nivea apresenta ampla distribuição nas áreas campestres da Cadeia do Espinhaço e Serra da Mantiqueira e nas restingas do sudeste brasileiro. Muito frequente no PEIB, em solo arenoso branco. Pode ser distinguida pelas longas brácteas involucrais alvas e gráceis.

\section{Eriocaulon L.}

Ervas perenes ou anuais, terrestres ou aquáticas. Folhas dispostas em roseta basal, lanceoladas a lineares, membranáceas a suculentas, fenestradas. Flores 3-meras, diplostêmones, com glândulas nas pétalas. Brácteas florais presentes. Flores estaminadas pediceladas, com sépalas livres ou unidas na base, pétalas do mesmo tamanho que as sépalas, providas de uma glândula interna negra, geralmente livres, anteras bitecas, tetraesporangiadas, dorsifixas, pistilódios presentes. Flores pistiladas sésseis, com pétalas livres, providas de uma glândula interna negra, ovário 2-3-locular, ramos estigmáticos 2 ou 3 , simples, ramos nectaríferos ausentes.

Eriocaulon apresenta distribuição pantropical, com algumas espécies estendendo-se à América do Norte e Ilhas Britânicas. No Brasil, esse gênero é representado por cerca de 60 de suas 450 espécies (Giulietti \& Hensold 1990, Giulietti et al. 2010). No PEIB está representado por apenas uma espécie.

2.1. Eriocaulon vaginatum Körn., Linnaea 27: 599. 1854.

Fig.1. G-I.

Planta ca. $45 \mathrm{~cm}$ alt. Rizoma ausente. Caule aéreo ca. $1 \mathrm{~cm}$ compr. Folhas dispostas em roseta, lanceoladas, 27-30 X 1,5-2,2 cm, glabrescentes, ápice obtuso. Espatas 12-18 cm compr., glabrescentes, truncadas, estriadas, ápice não dilatado. Escapos 16-36 cm compr., glabros, multicostados, livres. Capítulos globosos, 10-15 mm diâm., não vivíparos; brácteas involucrais nunca superando o capítulo, cremes, dispostas em 4 séries, obovais, glabras, ápice obtuso. Brácteas florais castanhas, oblongas, vilosas, ápice agudo. Flores estaminadas ca. 3,5 mm compr.; pedicelo ca. $1 \mathrm{~mm}$ compr., glabro; sépalas castanhas, unidas na base, oblanceoladas, pilosa na face externa, glabra na face interna, ápice obtuso, ciliado; pétalas hialinas, ovaladas, glabras, ápice agudo, piloso; anteras negras; pistilódios 3 , papilosos. Flores pistiladas ca. $3 \mathrm{~mm}$ compr.; sépalas castanhas, oblanceoladas, glabras na face interna, pilosas na face externa, ápice obtuso, ciliado; pétalas oblanceoladas, pilosas, ápice obtuso, ciliado; ramos estigmáticos bífidos.

Material examinado: Monjolinho, 19.IX.1940, M. Magalhães 483 (SPF).

Eriocaulon vaginatum apresenta ampla distribuição na América. No PEIB foi coletada apenas uma vez, em 1940, e os dados da etiqueta indicam que a espécie era frequente. Porém, não foi encontrada nas excursões mais recentes. Como muitos representantes de Eriocaulon, apresenta fenestras na base da folha, sendo facilmente distinta das demais Eriocaulaceae do PEIB.

\section{Leiothrix Ruhland}

Ervas perenes ou anuais, terrestres ou aquáticas. Folhas em roseta, cilíndricas a lanceoladas, não fenestradas. Flores 3-meras, isostêmones, sem glândulas nas pétalas. Brácteas florais presentes. Flores estaminadas pediceladas, sépalas livres; estames com filetes livres; anteras biteca, tetraesporangiadas, brancas, basifixas, pistilódios au- 

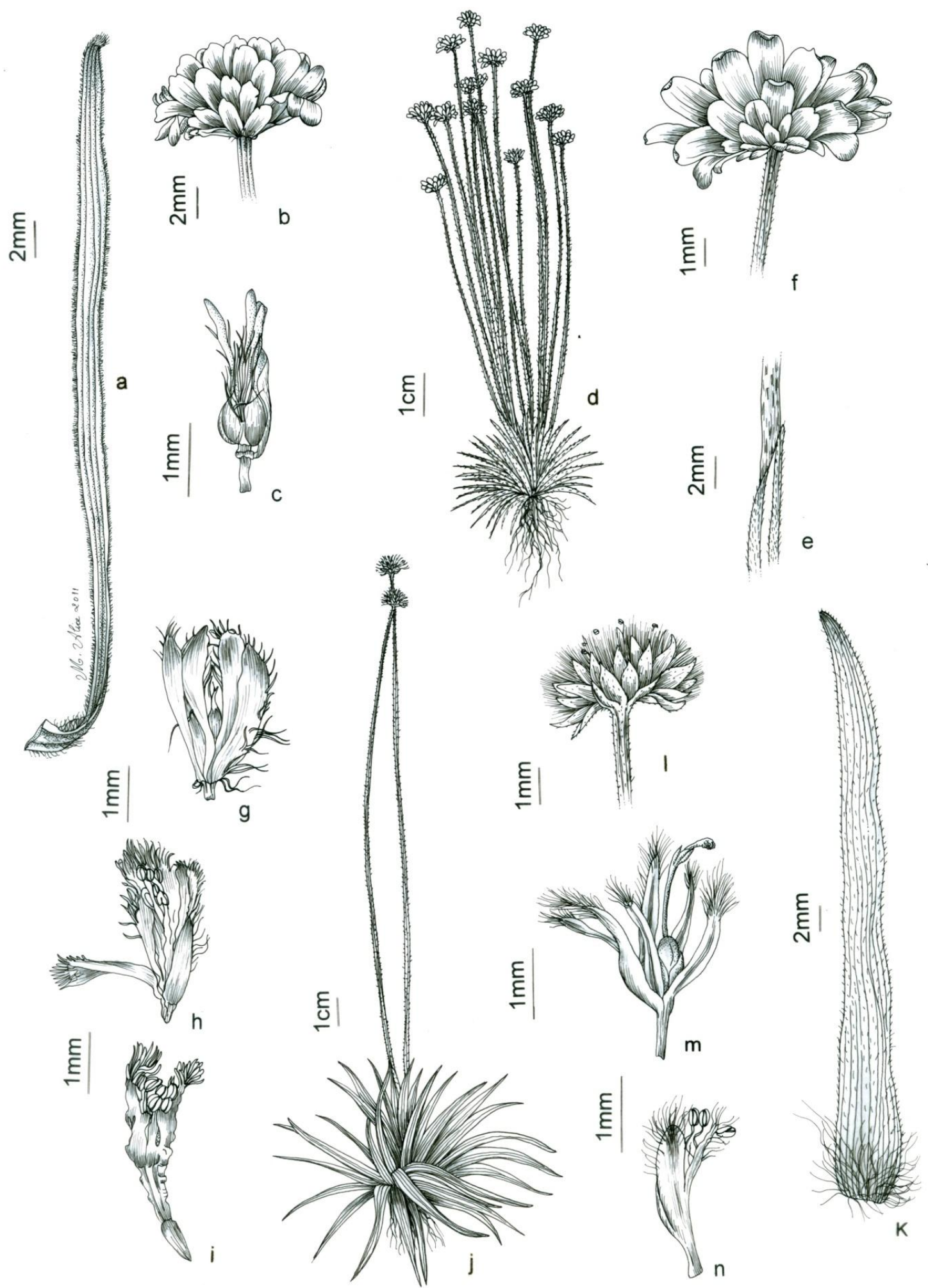

Fig. 1. a-c. Comanthera linearis: a. face adaxial da folha; b. capítulo; c. Flor pistilada. d-f. C. nivea: d. hábito; e. ápice da espata; f. capítulo. g-l. Eriocaulon vaginatum: g. flor pistilada; h. flor estaminada; i. flor estaminada com a brácteas removidas. j-n. Leiothrix flavescens: j. hábito; k. face adaxial da folha; I. capítulo; m. flor pistilada; n. flor estaminada. (a-c Krieger s.n. CESJ 15257; d-f Forzza 1835; g-i Magalhães 483; j-n Forzza 3578). 
sentes. Flores pistiladas sésseis, pétalas do mesmo tamanho que as sépalas; ovário 3-locular, ramos estigmáticos simples; ramos nectaríferos geralmente inseridos no estilete abaixo do nível de divergência dos ramos estigmáticos.

Leiothrix é um gênero composto por 49 espécies endêmicas da América do Sul. No Brasil, o gênero ocorre nas montanhas da Cadeia do Espinhaço (Bahia e Minas Gerais), nas Serra da Mantiqueira e do Mar e nas restingas litorâneas (Giulietti 1996, Giulietti et al. 2010). Para o PEIB é referida apenas uma espécie, Leiothrix flavescens (Bong.) Ruhland.

3.1. Leiothrix flavescens (Bong.) Ruhland in Engl., Pflanzenr. 4 : 231. 1903

Fig.1. J-N.

Planta 18-36 cm alt. Rizoma ausente. Caule aéreo restrito à roseta. Folhas em roseta, lineares a lanceoladas, 4,5-5,7 X 0,4-0,6 cm, hirsutas, ápice arredondado. Espatas 4,5-7,5 cm compr., hirsutas, fendidas obliquamente, estriadas, ápice não dilatado. Escapos 17,5-32 cm compr., velutinos, multicostados, livres. Capítulos semiglobosos, ca. $8 \mathrm{~mm}$ diâm., não vivíparos; brácteas involucrais nunca superando o capítulo, castanhas, dispostas em 3 séries, lanceoladas, glabras, ciliadas, ápice agudo. Brácteas florais castanhas, oblanceoladas, vilosas, ápice acuminado. Flores estaminadas ca. $3 \mathrm{~mm}$ compr., pedicelo ca. $1 \mathrm{~mm}$ compr., glabro; sépalas castanho-hialinas, oblanceoladas, glabras, ciliadas, ápice obtuso; tubo da corola hialino; anteras alvas; pistilódios 3, papilosos. Flores pistiladas ca. $2 \mathrm{~mm}$ compr.; sépalas hialinas, lanceoladas, hirsutas, ápice agudo; pétalas hialinas, lanceoladas, glabras, ciliadas, ápice agudo; ramos estigmáticos simples, maiores que os ramos nectaríferos.

Material examinado: s.I., 29.IX.1970, L. Krieger \& U.C. Câmara s.n. (CESJ 9372, RB, SPF); s.I., 30.IX.1970, U.C. Câmara s.n. (CESJ 9406, RB, SPF); s.I., 3.XI.1973, U.C Câmara s.n. (CESJ 13284, SPF); s.l., 13.XI.1973, U.C. Câmara 158 (CESJ, RB, SPF); s.I., 20.VI.1991, F.R.S. Pires s.n. (CESJ 24770, SPF); Pico Pião, 10.II.2001, M.A. Heluey et al. 51 (CESJ, RB, SPF); s.I., 22.VI.2001, M.A. Heluey \& A. Valente 145 (CESJ); trilha entre Lago dos Espelhos e Monjolinho, 18.IX.2007, C. Sarquis et al. 4 (K, RB, SPF); caminho entre Lombada e Cruzeiro, 19.IX.2007, C. Sarquis et al. 14 (MBM, NY, RB); Lombada, 27.X.2004, R.C. Forzza et al. 3578 (K, RB, SPF).

Leiothrix flavescens apresenta ampla distribuição na América do Sul. No PEIB, ocorre em solo arenoso ou encharcado, formando grandes populações. Além das características do pistilo, é distinta das demais Eriocaulaceae pelas folhas com ápice arredondado e capítulos amarelados.

\section{Paepalanthus Mart.}

Ervas terrestres, perenes ou anuais, acaulescentes ou caulescentes, rizoma presente ou ausente. Folhas em roseta basal, raramente distribuídas ao longo do caule, espiraladas, lineares a lanceoladas, membranáceas a coriáceas, não fenestradas. Flores 23-meras, sem glândulas nas pétalas, isostêmones. Brácteas florais presentes. Flores estaminadas pediceladas, sépalas unidas na base; pétalas unidas; estames 2 ou 3, filetes livres ou epipétalos, anteras bitecas, tetraesporangiadas, dorsifixas; pistilódios presentes. Flores pistiladas sésseis, raramente com curto pedicelo, sépala livres ou unidas na base; pétalas do mesmo tamanho que as sépalas, livres; ovário 2-3locular, ramos estigmáticos 2 ou 3 , simples ou bífidos, partindo da mesma altura dos ramos nectaríferos.

Paepalanthus inclui cerca de 480 espécies, sendo três ou quatro da África e as demais das Américas, ocorrendo desde a América Central até o Uruguai (Giulietti et al. 1996). É o gênero que apresenta maior variação morfológica dentro de Eriocaulaceae, além de ser um dos mais complexos quanto á delimitação da espécie. Análises filogenéticas vêm demonstrando que Paepalanthus é polifilético (Giulietti et al. 2000, Andrade et al. 2010), porém nenhuma nova proposta de classificação foi realizada até o momento. No PEIB são encontradas 16 espécies.

4.1. Paepalanthus acuminatus Ruhland in Engl., Pflanzenr. 4-30: 217. 1903.

Fig.2. A-C.

Planta $8-13 \mathrm{~cm}$ alt. Rizoma ausente. Caule aéreo 1,2-1,5 cm compr. Folhas em roseta, lineares, 5,5-10,2 X 0,3-0,6 cm, hirsutas, ápice acuminado. Espatas 1,7-3,5 cm compr., seríceas, fendidas obliquamente, não estriadas, ápice não dilatado. Escapos 6,5-8 cm compr.; seríceos, tricostados, livres. Capítulos semiglobosos, 610 mm diâm., não vivíparos; brácteas involucrais superando o capítulo, estramíneas, dispostas em 3 séries, lanceoladas, glabras, ciliadas, ápice acuminado. Flores 3-meras. Brácteas florais castanho claras, lanceoladas, velutinas, ápice agudo. Flores estaminadas ca. $3 \mathrm{~mm}$ compr.; pedicelo ca. 0,2 mm compr., com longos tricomas; sépalas castanhas, obovais, glabras, ápice agudo, viloso; tubo da corola castanho; anteras creme; pistilódios 3 , papilosos. Flores pistiladas ca. 3 mm compr.; sépalas estramíneas, lanceoladas, glabras, margem velutina, ápice agudo; ramos estigmáticos simples, menores do que os ramos nectaríferos.

Material examinado: s.I., 29.IX.1970, U.C. Câmara s.n. (CESJ 9373, SPF); s.I., 30.IX.1970, U.C. Câmara s.n. (CESJ 9410, RB, SPF); s.I., 1.XI.1973, U.C. Câmara s.n. (CESJ 13276, SPF); s.I., 25.II.1977, M.P. Coons 333 (SPF); s.l., 17.IV.1993, A. Ferreira s.n. (CESJ 26618); s.l., 8.XII.1998, G. Martinelli et al. 15268 (RB); extremidade norte do parque, A.S.M. Valente \& F.S. Araújo 173 (CESJ, RB); trilha Cachoeira dos Macacos - Ponte de Pedra, 16.III.2005, R. Dias-Melo et al. 205 (RB, K); Lago das Miragens, F.M. Ferreira et al. 1101 (CESJ, RB); Pico do Pião, 14.V.1970, D. Sucre \& L. Krieger 6793 (RB).

Paepalanthus acuminatus é endêmica do PEIB, ocorrendo frequentemente em beiras de trilhas e bordas de mata, sob o sol. É facilmente distinta das 
demais espécies pelas folhas densamente hirsutas e brácteas involucrais externas ultrapassando 0 diâmetro do capítulo e de coloração estramínea.

4.2. Paepalanthus calvus Körn. in Mart. \& Eichler, FI. bras. 3(1): 391. 1863. Tipo: Brasil, Minas Gerais: "Minas Geraes, alt. 7000 ped.", s.d., G. Langsdorff s.n. (holótipo B!; isótipo LE!).

= Paepalanthus ibitipocensis Silveira, FI. serr. min.: 41. 1908. Tipo: Brasil, Minas Gerais: "Serra de Ibitipoca". VI.1896, H. Magalhães s.n. (267 in herb. Silveira) (holótipo R!). Syn. nov.

Fig.2. D-E.

Planta 20-28 cm alt. Rizoma ausente. Caule aéreo $0,5-1,5 \mathrm{~cm}$ compr. Folhas dispostas em roseta, lanceoladas, 4,7-10 X 0,4-0,8 cm, glabras, ápice agudo. Espatas $5-11 \mathrm{~cm}$ compr., pilosas, fendidas obliquamente, estriadas, ápice não-dilatado. Escapos 15-46 cm compr., glabros, multicostados, livres. Capítulos semiglobosos, 710 mm diâm., não vivíparos; brácteas involucrais nunca superando o capítulo, castanho-escuras, dispostas em 34 séries, ovais, glabras, ciliadas no ápice agudo. Flores 3meras. Brácteas florais lineares, verdes com ápice negro, glabras, ápice agudo, ciliado. Flores estaminadas ca. 2,5 $\mathrm{mm}$ compr.; pedicelo ca. 0,4 mm compr., glabro; sépalas esverdeadas com ápice negro, obovais, glabras, ápice obtuso, ciliado; tubo da corola hialino; anteras negras; pistilódios 3, papilosos. Flores pistiladas ca. $2 \mathrm{~mm}$ compr.; sépalas esverdeadas com ápice negro, obovais, glabras, ápice agudo, ciliado; pétalas hialinas, oblongas, glabras, ápice obtuso, ciliado; ramos estigmáticos bífidos, menores que os ramos nectaríferos.

Material examinado: s.I., 1.XI.1973, U.C. Câmara s.n. (CESJ 13280, RB, SPF); trilha para Lombada, 15.VII.2005, M.L.O. Trovó et al. 192 (SPF); Lago dos Espelhos, 18.IX.2007, C. Sarquis et al. 7 (RB).

Paepalanthus calvus é endêmica do Domínio Atlântico. No PEIB pode ser encontrada em locais úmidos e sombreados com relativa frequência, mas não forma grandes populações. É distinta das demais espécies pelos longos escapos multicostados e pelas brácteas involucrais escuras.

Paepalanthus calvus apresenta como características diagnósticas as folhas glabrescentes (geralmente glabras em materiais de herbário), capítulos largos e brácteas involucrais castanho-escuras (Koernicke 1863, Trovó \& Sano 2010). Esta espécie ocorre ao longo da Serra da Mantiqueira, e, nesta região, assemelha-se a Paepalanthus striatus Ruhland. Silveira (1908) descreveu P. ibitipocensis coletado na Serra de Ibitipoca, Minas Gerais, região pertencente ao Complexo da Mantiqueira ( $H$. Magalhães s.n.; R). e comenta que a espécie apresenta folhas pubescentes como uma de suas características marcantes. No entanto, no material depositado em R ( $H$. Magalhães s.n.; R), percebe-se claramente que as folhas perderam a maioria dos tricomas, fato comum em espécimes de herbário. As características da pilosidade da espata e do ápice das brácteas involucrais, também citadas como diagnósticas (Silveira 1908, 1928), encontram-se dentro da variação morfológica encontrada em P. calvus (Koernicke 1863, Trovó \& Sano 2010). Os espécimes typus possuem espatas bastante longas, maiores que as folhas, característica rara nas espécies ocorrentes no complexo da Matiqueira. Com base nestas informções e após cuidadosa análise da coleção-tipo, propomos que $P$. ibitipocensis seja tratado como sinônimo de P. calvus.

4.3. Paepalanthus cephalopus Silveira \& Ruhland in Engl., Pflanzenr. 4-30: 165. 1903.

Planta 1-3 cm alt. Rizoma ausente. Caule aéreo, 0,5-1 $\mathrm{mm}$ compr. Folhas dispostas em roseta, lineares, 3-6 X 0,5-1 mm, pilosas em ambas as faces, ápice agudo. Espatas 0,3-1 cm, glabrescentes, fendidas obliquamente, não estriadas, ápice não dilatado. Escapos 2-4 cm compr., pilosos, multicostados, livres. Capítulos semiglobosos, 2-3 $\mathrm{mm}$ diâm., vivíparos; brácteas involucrais nunca superando o capítulo, castanhas, em 3 séries, elípticas, pilosas na face abaxial, ciliadas, ápice obtuso. Flores 3-meras. Brácteas florais castanhas, oblongas, glabras, ciliadas, ápice agudo. Flores estaminadas ca. $2 \mathrm{~mm}$ compr.; pedicelo ca. $0,5 \mathrm{~mm}$ compr., com longos tricomas; sépalas castanhas, obovais, glabras, ciliadas, ápice agudo; tubo da corola hialino; anteras creme; pistilódios 3 , papilosos. Flores pistiladas ca. $2 \mathrm{~mm}$ compr.; sépalas castanhas, obovais, pilosas na face abaxial, ciliadas, ápice obtuso; pétalas hialinas, elípticas, glabras, ciliadas, ápice agudo; ramos estigmáticos bífidos, do mesmo tamanho que os ramos nectaríferos. (B, holótipo).

Material examinado: VII.1896, H. Magalhães 1374

Paepalanthus cephalopus é endêmica do PEIB de onde é conhecida apenas pelo holótipo. Assim como Paepalanthus viridulus, apresenta capítulos vivíparos porém pode ser diferenciada por possuir folhas menores e caule curto, não ramificado. O material tipo de $P$. cephalopus apresenta o mesmo coletor e número de coleta de um dos tipos de $P$. viridulus. Porém, Ruhland (1903) segregou os espécimes em dois táxons distintos, posição esta aceita no presente estudo. Apesar do longo período de coletas na área do Parque e no seu entorno, esta espécie não foi localizada.

4.4. Paepalanthus dupatya Mart. ex Koern., in Mart. \& Eichler, FI. bras. 3(1): 410. 1863.

Fig.2. F-H.

Planta 46-50 cm alt. Rizoma ausente. Caule aéreo 1,8-2,5 cm compr. Folhas em roseta, lineares, 13$23 \times 0,4-0,7 \mathrm{~cm}$, hirsutas, ápice agudo. Espatas 9,5-13 cm compr., hirsutas, estriadas, ápice não dilatado. Escapos 13-48 cm compr., esparsamente pilosos, tricostados, unidos. Capítulos urceolados, ca. $4 \mathrm{~mm}$ diâm., não vivíparos; brácteas involucrais nunca superando o capítulo, castanhas, dispostas em 3 séries, 

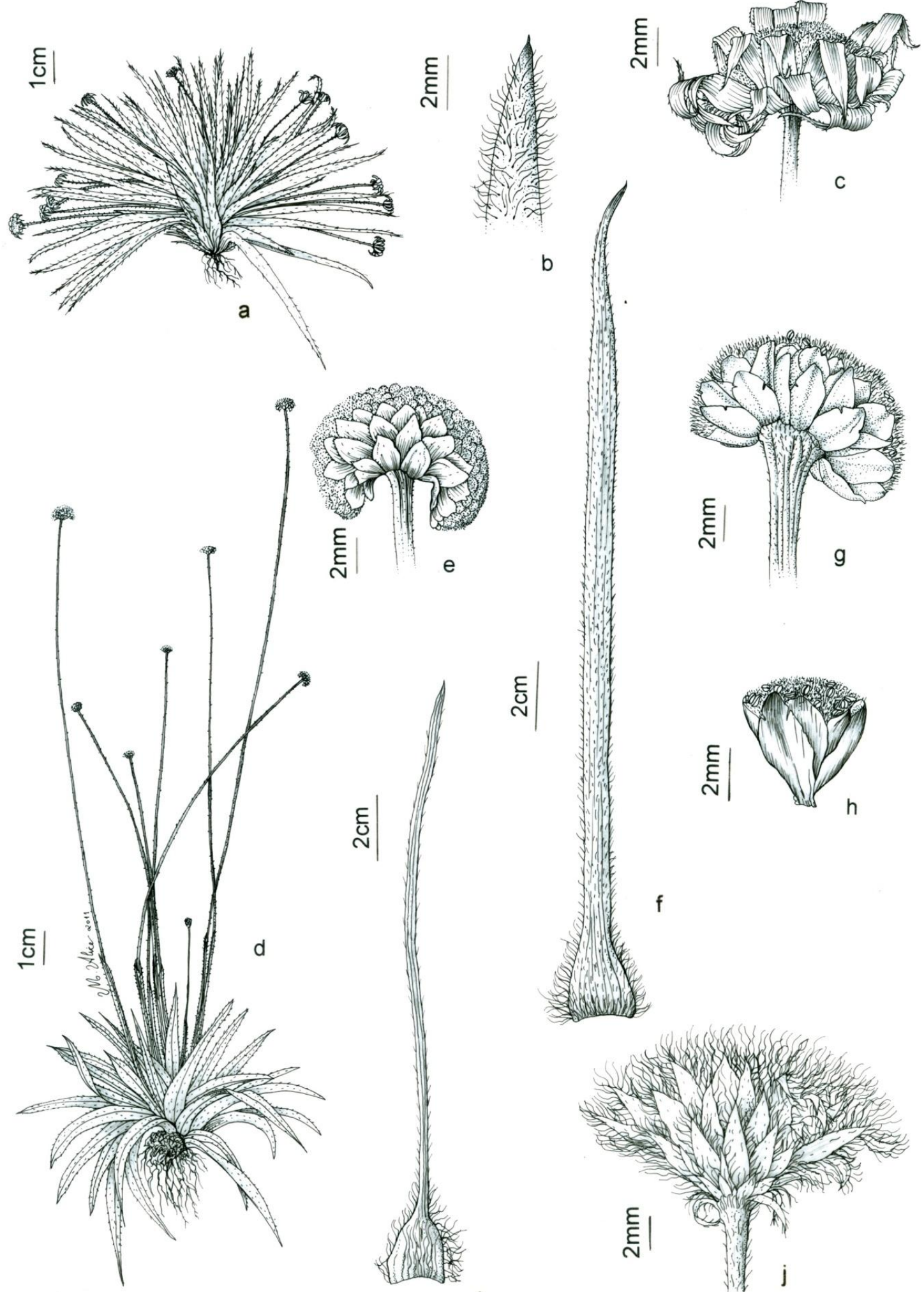

i

Fig. 2. a-c. Paepalanthus acuminatus: a. hábito; b. detalhe dos tricomas nas folhas; c. capítulo. d-e. P. calvus: d. hábito; e. capítulo. f-h. $P$. dupatya: f. face adaxial da folha; g. inflorescência composta; h. capítulo solitário. i-j. $P$. elongatus: i. face adaxial da folha; j. capítulo. (a-c Dias-Melo 205; d-e Sarquis 7; f-h Sarquis 13; i-j Morato 21). 
ovais, glabras, ápice agudo. Flores 3-meras; brácteas florais esverdeadas, oblongas, glabras, ápice acuminado, velutino. Flores estaminadas ca. $3 \mathrm{~mm}$ compr.; pedicelo ca. $1 \mathrm{~mm}$ compr., com longos tricomas; sépalas verdes, obovais, glabras, ápice obtuso, ciliado; tubo da corola hialino; anteras alvas a alaranjadas; pistilódios 3, papilosos. Flores pistiladas ca. 3,5 mm compr.; sépalas verdes, oblanceoladas, glabras, ápice obtuso, ciliado; pétalas hialinas, lanceoladas, glabras, ápice agudo, piloso; ramos estigmáticos bífidos, maiores que os ramos nectaríferos.

Material examinado: próximo à Lombada, 27.VII.1991, M. Eiterer s.n. (CESJ 24866, SPF); caminho entre a Lombada e o Cruzeiro, 19.IX.2007, C. Sarquis et al. 13 (K, RB, SPF).

Paepalanthus dupatya é restrita ao Domínio Atlântico, e no PEIB, ocorre com baixa frequência nos campos, sempre em local ensolarado. Possui como característica marcante os escapos unidos até o ápice, de modo que os capítulos também se encontram unidos, porém facilmente isolados. Suas folhas e espatas hirsutas também são caracteres úteis no reconhecimento da espécie.

4.5. Paepalanthus elongatus (Bong.) Körn. in Mart. \& Eichler, FI. bras. 3(1): 312. 1863.

Fig.2. I-J.

Planta 41-59 cm alt. Rizoma presente, ca. $1 \mathrm{~cm}$ compr. Caule aéreo 3-5 $\mathrm{mm}$ compr. Folhas em roseta, lineares, 8-20 X 0,1-0,3 cm, ciliadas, base velutina, ápice arredondado, seríceo. Espatas, 8-11 cm compr., glabras a seríceas no ápice, fendidas obliquamente, estriadas, ápice não-dilatado. Escapos 29-59cm compr., seríceos, multicostados, livres. Capítulos discóides, 5-10 mm diâm., não vivíparos; brácteas involucrais superando o capítulo, castanho-escuras, dispostas em 3-5 séries, lanceoladas, glabras, margem hirsuta, ápice acuminado. Flores 2-meras. Brácteas florais hialinas com centro castanho, lanceoladas, pilosas na margem, ápice acuminado. Flores estaminadas ca. 2,5 mm compr.; pedicelo ca. 0,1 mm compr., glabro; sépalas hialinas com ápice castanho, obovais, glabras, ápice obtuso, seríceo; tubo da corola amarelado; anteras alvas, pistilódios 2, papilosos. Flores pistiladas ca. 1,9 mm compr.; sépalas castanhas, oblanceoladas, glabras, ápice agudo, viloso; pétalas hialinas a castanhas, oblongas, ápice obtuso, viloso; ramos estigmáticos bífidos, maiores que os ramos nectaríferos.

Material selecionado: s.I., 16.IX.1940, M. Magalhães 433 (SPF); s.I., 1.X.1970, L. Krieger s.n. (BHCB n.v., CESJ 9452, MBM n.v.); s.l., 1.XI.1973, U.C. Câmara 153 (CESJ); trilha Prainha para Monjolinho, 30.III.2004, C. Morato et al. 21 (CESJ, K, NY, RB, SPF); s.I., 8.VI.1965, fl., J. G. Kuhlmann 5224 (RB); s.I., 23.III.1988, P.M. Andrade \& M.A. Drumond 1133 (RB, SPF); s.I., 8.II.2001, F.S. Araújo et al. 7 (CESJ, RB, SPF); trilha para o Pico do Pião, 10.III.2004, R.C. Forzza et al. 3100 (CESJ, HUEFS, K, MBM, NY, R, RB,
SPF); caminho para a Ponte de Pedra, 13.VII.2005, M.L.O. Trovó et al. 172 (RB, SPF); Lago dos Espelhos, 18.IX.2007, C. Sarquis et al. 6 (RB).

Paepalanthus elongatus tem ampla distribuição no Brasil e é frequente no PEIB, sendo encontrada sob diversas condições como campos graminosos, afloramentos e em locais mais sombreados. É facilmente distinguida das demais espécies pelas folhas lineares, flores dímeras e brácteas involucrais reflexas, castanhas e densamente ciliadas.

4.6 Paepalanthus euryphyllus Ruhland in Engl., Pflanzenr. 4: 130. 1903.

Planta 5-27 cm alt. Rizoma ausente. Caule aéreo, 0,5-1 cm compr. Folhas em roseta, lanceoladas, 4-6,5 X 0,6-0,9 cm, glabras, ápice agudo. Espatas 1,5-4 cm compr., glabras, fendidas obliquamente, não estriadas, ápice não dilatado. Escapos 5,5-8 cm compr., glabros, multicostados, livres. Capítulos semiglobosos, 3$6 \mathrm{~mm}$ diâm., não vivíparos; brácteas involucrais nunca superando o capítulo, castanho-escuras, dispostas em 3 séries, elípticas, glabras, ciliadas, ápice obtuso. Flores 3meras. Brácteas florais castanhas, oblongas, pilosas na face abaxial, ciliadas, ápice agudo. Flores estaminadas ca. 2,5 mm compr.; pedicelo ca. 0,5 mm compr., com longos tricomas; sépalas castanhas, obovais, glabras, ciliadas, ápice agudo; tubo da corola hialino; anteras creme; pistilódios 3, papilosos. Flores pistiladas ca. 2,5 mm compr.; sépalas castanhas, obovais, pilosas na face abaxial, ciliadas, ápice obtuso; pétalas hialinas, elípticas, glabras, ciliadas, ápice agudo; ramos estigmáticos simples, do mesmo tamanho que os ramos nectaríferos.

Material examinado: VII.1896, H. Magalhães 1654 (B, Holótipo; B, Isótipo).

Paepalanthus euryphyllus é endêmica do PEIB de onde é conhecida apenas pela coleção-tipo, apesar dos anos de coletas regulares realizadas na área. É facilmente distinta das demais espécies por possuir folhas membranáceas.

4.7. Paepalanthus exiguus Körn. in Mart. \& Eichler, FI. bras. 3(1): 314. 1863.

Fig.3. A-B.

Planta 2-9,3 cm alt. Rizoma ausente. Caule aéreo 1-5 mm compr. Folhas ao longo do caule, lineares, 5-10 X 0,2-0,4 mm, glabra, ápice agudo. Espatas 0,5-1 $\mathrm{cm}$ compr., setosas no ápice, fendidas obliquamente, não estriadas, ápice não dilatado. Escapos 1-8 cm compr., glabrescentes, tricostados, livres. Capítulos semiglobosos, 1-3 mm diâm., não vivíparos; brácteas involucrais nunca superando o capítulo, castanhas no centro e hialinas na lateral, dispostas em 3 séries, obovais, glabras, margem velutina, ápice obtuso. Flores 2-meras. Brácteas florais hialinas com ápice castanho, obovais, glabras, ciliadas, ápice obtuso. Flores estami- 

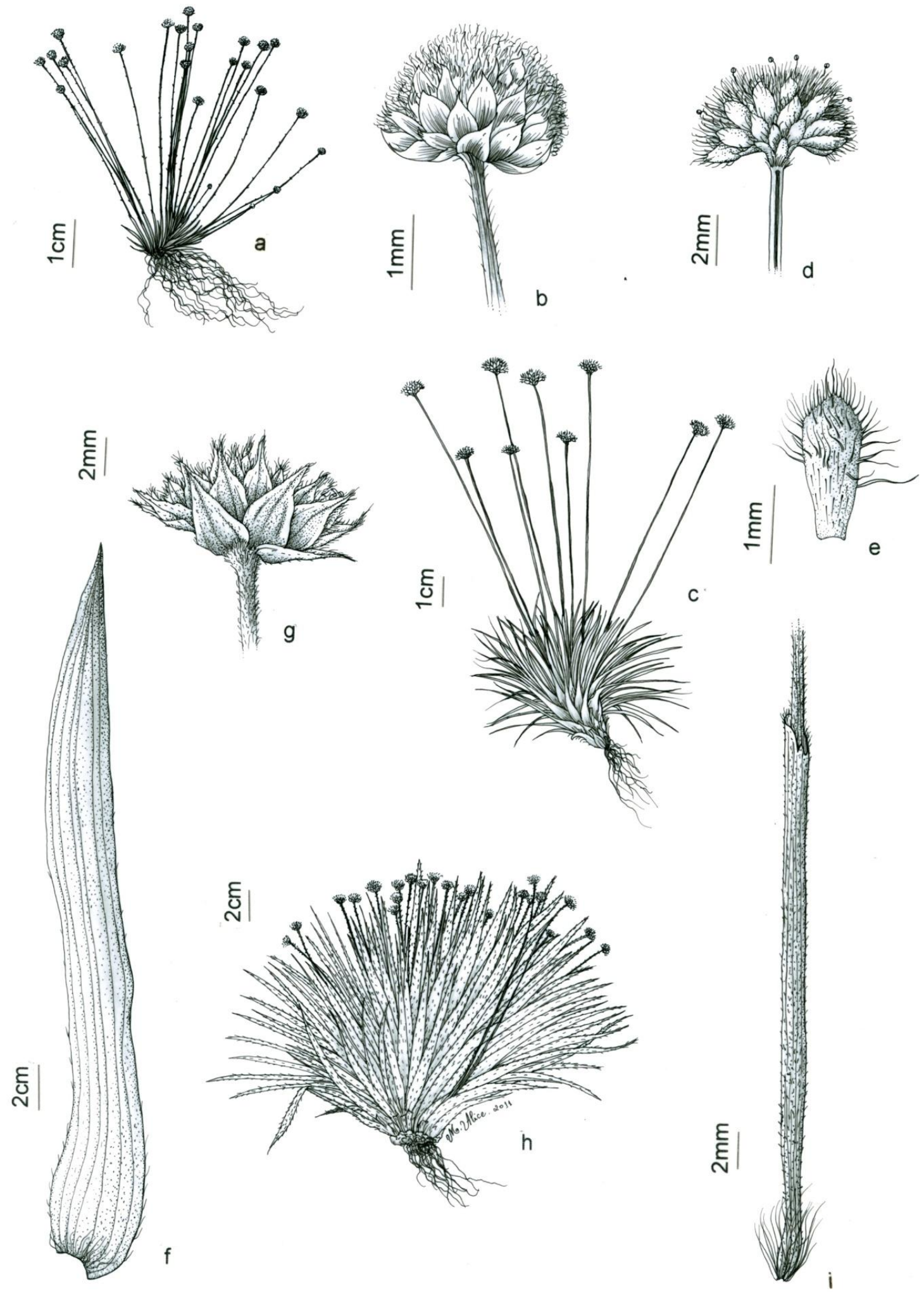

Fig. 3. a-b. Paepalanthus exiguus: a. hábito; b. capítulo. c-e. P. freyreissii: c. hábito; d. capítulo; e. face abaxial da bráctea floral. f-g. P. harmsii: f. face adaxial da folha; g. capítulo. h-i. P. henriquei: h. hábito; i. detalhe da espata. (a-b Silva 1275; c-e Trovó 177; f-g Morato 19; h-i Morato 16). 
nadas ca. 1,2 mm compr., pedicelo ca. 0,1 mm compr, glabro; sépalas hialinas, obovais, glabras, ápice obtuso, piloso; tubo da corola hialino; anteras creme; pistilódios 2, papilosos. Flores pistiladas ca. $1 \mathrm{~mm}$ compr.; sépalas hialinas, obovais, glabras, ápice obtuso, piloso; pétalas castanhas, oblongas, glabras, ápice obtuso, piloso; ramos estigmáticos bífidos, do mesmo tamanho dos ramos nectaríferos.

Material selecionado: s.I., 14.V.1970, L. Krieger s.n. (CESJ 9159, RB, SPF); s.l., 8.II.2001, M.A. Heluey et al. 27 (CESJ); trilha para Cachoeirinha, 23.II.1992, M. Eiterer 82 (CESJ, SPF); proximidades da cantina, 9.III.2004, R.C. Forzza et al. 3091 (K, RB); idem, 9.III.2004, R.C. Forzza et al. 3090 (RB); margem da estrada em direção à ponta do parque, 5.II.2004, B.R. Silva et al. 1275 (RB); trilha Monjolinho-Lagoa Seca, 30.III.2004, C. Morato et al. 18 (RB).

Paepalanthus exiguus apresenta ampla distribuição no Brasil, e no PEIB, ocorre normalmente em solo arenoso, formando touceiras, mas também pode ser encontrada em solo úmido. Esta espécie é facilmente diferenciada das demais pelo pequeno porte e pelas flores dímeras.

4.8. Paepalanthus freyreissii (Thumb.) Körn. in Mart. \& Eichler, FI. bras. 3(1): 370. 1863.

Fig.3. C-E.

Planta 4,5-21 cm alt. Rizoma presente ou não. Caule aéreo $0,7-7,2 \mathrm{~cm}$. Folhas ao longo do caule, lineares, 23-50 X 0,5-2 mm, glabrescentes, ápice acuminado. Espatas 1,2-2,1 cm compr., setosas, fendidas obliquamente, estriadas, ápice não dilatado. Escapos 6-13 cm compr., glabrescentes, tricostados, livres. Capítulos semiglobosos, 4-7 mm diâm., não vivíparos; brácteas involucrais nunca superando o capítulo, castanho-escuras, dispostas em 4 séries, ovais, glabras, margem ciliada, ápice obtuso. Flores 3-meras. Brácteas florais castanhas, lanceoladas, glabras, ápice agudo, velutino. Flores estaminadas ca. $2 \mathrm{~mm}$ compr.; pedicelo ca. 0,3 $\mathrm{mm}$ compr., com longos tricomas; sépalas castanhas, obovais, glabras, margem serícea, ápice obtuso; tubo da corola hialino; anteras negras; pistilódios 3, papilosos. Flores pistiladas ca. 2,3 mm compr.; sépalas castanhas, oblanceoladas, glabras, margem serícea, ápice agudo; pétalas hialinas, obovais, glabras, ápice agudo, piloso; ramos estigmáticos bífidos, maiores que os ramos nectaríferos.

Material selecionado: margens do Rio do Salto, 3.XI.1973, U.C. Câmara 160 (CESJ, RB, SPF); Lago dos Espelhos, 18.IX.2007, C. Sarquis et. al. 8 (K, RB); trilha Monjolinho - Lagoa Seca, 1.VII.2006, R. C. Forzza et al. 4221 (K, RB, SPF); Janela do Céu, 16.VII.2005, M.F. Santos et al. 46 (RB, SPF); caminho para a Ponte de Pedra, 13.VII.2005, M.L.O. Trovó et al. 177 (SPF).

Paepalanthus freyreissii tem distribuição restrita à Cadeia do Espinhaço e Serra da Mantiqueira. No PEIB ocorre em ambientes úmidos e sombreados, sendo frequente próximo a cursos d'água e grutas.
Semelhante a Paepalanthus miser, pode ser distinguida pelas folhas lineares e rígidas, além das brácteas involucrais castanhas.

4.9. Paepalanthus harmsii Ruhland in Engl., Pflanzenr. 4-30: 216. 1903.

Fig.3. F-G.

Planta 27-34 cm alt. Rizoma ausente. Caule aéreo 2,5-3,5 cm. Folhas dispostas em roseta, lanceoladas, $11-30 \times 0,7-2,7 \mathrm{~cm}$, glabrescentes, ápice acuminado. Espatas 5-9,5 cm compr., glabrescentes, fendidas obliquamente, não estriadas, ápice não dilatado. Escapos 6-27 cm compr., tomentosos, multicostados, livres. Capítulos semiglobosos, 7-12 mm diâm., não vivíparos; brácteas involucrais superando o capítulo, estramíneas, dispostas em 5 séries, ovais, tomentosas, ápice acuminado. Flores 3-meras. Brácteas florais castanho-claras, lineares, margem velutina, ápice acuminado. Flores estaminadas ca. $3,5 \mathrm{~mm}$ compr.; pedicelo ca. 0,7 mm compr., glabro; sépalas hialinas, obovais, glabras, ápice agudo, densamente ciliado; tubo da corola hialino; anteras alvas; pistilódios 3, papilosos. Flores pistiladas ca. $4 \mathrm{~mm}$ compr.; sépalas hialinas, lanceoladas, glabras, margem velutina, ápice agudo; pétalas hialinas, lanceoladas, vilosas, ápice agudo; ramos estigmáticos bífidos, maiores que ramos nectaríferos.

Material selecionado: s.l., s.d., U.C. Câmara s.n. (CESJ 9411, RB); s.I., V.1970, L. Krieger s.n. (CESJ 9147, SPF); s.I., 30.IX.1970, P.I.S. Braga et al. 1918 (MICH n.v., RB); Monjolinho, 19.IX.2006, R.C.Forzza et al. 4251 (CESJ, K, RB); trilha entre a Lombada e o Pico do Pião, 11.III.2004, R. C. Forzza et al. 3241 (RB); próximo à Gruta dos Viajantes, 18.IX.2007, C. Sarquis et al. 1 (MBM, RB); trilha Monjolinho Lagoa Seca, 30. III.2004, C. Morato et al. 19 (RB); entre a Mata Grande e a Ponte de Pedra, 30.III.2004, R.C. Forzza et al. 3280 (RB, SPF); Janela do Céu, 16.VII.2005, M.F. Santos et. al. 47 (SPF); trilha para Lagoa Seca, 15.III.2005, L. Monguilhot et al. 116 (SPF).

Paepalanthus harmsii tem distribuição restrita ao Domínio Atlântico e no PEIB é frequente nas bordas de mata, em locais úmidos e sombreados. É uma espécie de fácil identificação devido às suas folhas largas e brácteas involucrais estramíneas, sendo que as externas ultrapassam o diâmetro do capítulo.

4.10. Paepalanthus henriquei Silveira \& Ruhland in Engl., Pflanzenr. 4-30: 129. 1903. Tipo: Brasil, Minas Gerais: "Serra de Ibitipoca", VI.1896, $H$. Magalhães 1372 (holótipo B!).

=Paepalanthus orthoblepharus Silveira, Floral. mont.: 62, tab. 35. 1928. Tipo: Brasil, Minas Gerais: "Serra de Ibitipoca" VI.1896, H. Magalhães s.n. (559 in herb. Silveira) (holótipo R!). Syn. nov.

Fig.3.

$\mathrm{H}-\mathrm{I}$. 
Planta 14-20 cm alt. Rizoma ausente. Caule aéreo 2,4-3,2 cm compr. Folhas dispostas em roseta, lineares, 7,3-16 X 0,2-0,5 cm, glabras a hirsutas, margem ciliada, ápice acuminado. Espatas 2-3,3 cm compr., truncadas, hirsutas, não estriadas, ápice não dilatado. Escapos 9,3-13,5 cm compr., hirsutos, tricostados, livres. Capítulos semiglobosos, 6-10 mm diâm., não vivíparos; brácteas involucrais nunca superando o capítulo, castanhas, dispostas em 3 séries, obovais, glabras, margem vilosa, ápice acuminado. Flores 3-meras. Brácteas florais castanhas, lanceoladas, glabras, margem serícea, ápice acuminado. Flores estaminadas ca. 3,5 mm compr.; pedicelo ca. $1 \mathrm{~mm}$ compr., glabro; sépalas castanhas, lanceoladas, glabras, margem vilosa, ápice agudo; tubo da corola hialino; anteras estramíneas; pistilódios 3, papilosos. Flores pistiladas ca. $2,5 \mathrm{~mm}$ compr.; sépalas castanhas, lanceoladas, glabras, margem vilosa, ápice agudo; pétalas hialinas, lanceoladas, glabras, margem vilosa, ápice acuminado; ramos estigmáticos bífidos, maiores do que os ramos nectaríferos.

Material examinado: s.I., 1.XI.1973, U.C. Câmara s.n. (CESJ 13275, RB, SPF); Lagoa Seca, 10.II.2001, R.C Forzza et al. 1842 (CESJ, RB, SPF); trilha Monjolinho Lagoa Seca, 30.III.2004, C. Morato et al. 16 (K, MBM, RB); Gruta do Monjolinho, 18.IX.2007, C. Sarquis et al. 3 (CESJ, $\mathrm{K}, \mathrm{RB}, \mathrm{SPF}$ ).

Paepalanthus henriquei é endêmica do PEIB, onde ocorre com pouca frequência sendo encontrada tanto em locais sombreados como sob o sol. É distinta das demais espécies do Parque por possuir escapos do mesmo tamanho que as folhas e espatas com ápice truncado.

Silveira \& Ruhland (Ruhland 1903) descreveram $P$. henriquei, coletado na Serra do Ibitipoca, Minas Gerais (H. Magalhães 1372; B). Este material possui a grafia de Álvaro da Silveira na etiqueta original da Comissão Geográfica e Geológica de Minas Gerais indicando o nome da espécie. Possui também a grafia de Wilhelm Ruhland em outra etiqueta. Estes autores tiveram pouco contato, sendo provável que a descrição da espécie deva-se apenas a Wilhelm Ruhland (Ruhland,1903), visto que não há nenhuma descrição anexada ao material que tenha sido feita à mão por Álvaro da Silveira. Silveira (1928) descreveu $P$. orthoblepharus coletado na Serra de Ibitipoca, Minas Gerais (H. Magalhães s.n.; R). Este material foi coletado na mesma data e na mesma localidade que o tipo de $P$. henriquei, sendo possível que façam parte da mesma coleção, uma vez que a numeração do material depositado em $B$ não é original, e foi colocada à posteriori. Portanto, é muito provável que Álvaro da Silveira, 25 anos após a publicação de $P$. henriquei, tenha descrito uma nova espécie com base em um material que pertence à mesma coleção tipo de uma espécie já descrita, dando a ele um outro nome. Mas, como no protólogo da espécie descrita por Ruhland \& Silveira (Ruhland 1903) há citação de um número de coleta (não original), e no material descrito por Silveira (1928) não há, é impossível concluir que $P$. orthoblepharus seja um nome supérfluo.
Ambos os espécimes apresentam folhas hirsutas a glabrescentes, inúmeros escapos do mesmo comprimento das folhas e brácteas involucrais castanho escuras. Silveira (1928) indicou a clara afinidade entre estas espécies, no entanto afirmou que poderiam ser distintas pelo indumento. Assim como todas as demais característics presentes no espécimem $(H$. Magalhães s.n.; R) e na descrição, o indumento das folhas de $P$. orthoblepharus está dentro da variação morfológica encontrada nos espécimes de $P$. henriquei coletados recentemente. Adicionalmente, ambos táxons possuem espatas curtas com ápice truncado, que é uma característica incomum em Paepalanthus. Com base nas coleções tipo e na variação morfológica encontrada em herbários e em campo, propomos que $P$. orthoblepharus seja tratado como sinônimo de $P$. henriquei.

4.11. Paepalanthus leiseringii Ruhland in Engl., Pflanzenr. 4: 216. 1903.

Planta $18 \mathrm{~cm}$ alt. Rizoma ausente. Caule aéreo ca. $1,5 \mathrm{~cm}$ compr. Folhas em roseta, lanceoladas, 14$16,5 \times 0,6-1 \mathrm{~cm}$, pilosas, ápice agudo. Espatas ca. $2 \mathrm{~cm}$ compr., não estriadas, glabrescentes, fendidas obliquamente, ápice não dilatado. Escapos 9,5-11,5 cm compr., glabrescentes, multicostados, livres. Capítulos semiglobosos, ca. $6 \mathrm{~mm}$ diâm., não vivíparos; brácteas involucrais superando o capítulo, castanho-escuras, dispostas em 3 séries, ovais, ciliadas, ápice acuminado. Flores 3-meras. Brácteas florais castanho-escuras, lanceoladas, velutinas no ápice agudo. Flores estaminadas ca. $3 \mathrm{~mm}$ compr., pedicelo ca. $1 \mathrm{~mm}$ compr., glabro; sépalas castanho-escuras, lanceoladas, ápice agudo, velutino, tubo da corola castanho, hialino; anteras castanhas; pistilódios 3, papilosos. Flores pistiladas ca. $2 \mathrm{~mm}$ compr.; sépalas castanho-escuras, ovais, ápice agudo, velutino; pétalas castanhas, lineares, ápice obtuso, piloso; amos estigmáticos bífidos, do mesmo tamanho dos ramos nectaríferos.

Material examinado: IV.1898, H. Magalhães 2915 (B, holótipo); IV.1898, H. Magalhães s.n. (R 140534, Herb. Silveira 239).

Paepalanthus leiseringii é conhecida apenas pelo material tipo que foi coletado na Serra do lbitipoca. É distinta das demais espécies por possuir brácteas involucrais castanho-escuras, sendo que as externas ultrapassam o do capítulo.

4.12. Paepalanthus macaheensis Körn., Kjöb. Vidensk. Meddel. 311. 1871.

Fig.4. A.

Planta 16-21 cm alt. Rizoma presente. Caule aéreo $3,6-4,8 \mathrm{~cm}$. Folhas dispostas ao longo do caule, lanceoladas, 2,7-6,8 X 0,5-0,8 cm, glabras, ápice acuminado. Espatas 2,5-4 cm compr., glabras, fendidas obliquamente, não estriadas, ápice não dilatado. Escapos 3,4-13,2 cm compr., glabros, tricostados, livres. Capítulos semiglobosos, 3-7 mm diâm., não vivíparos; brácteas 

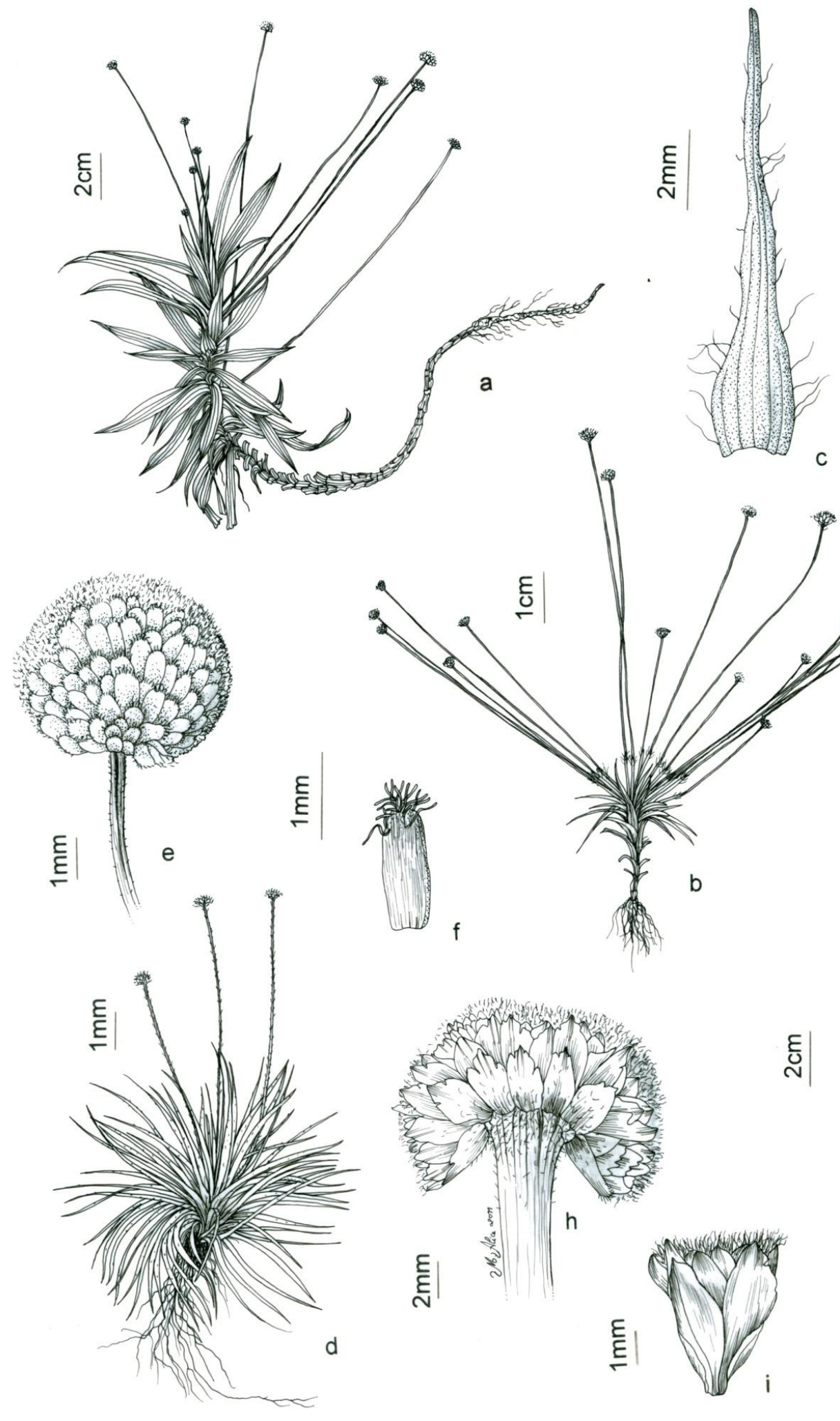

a
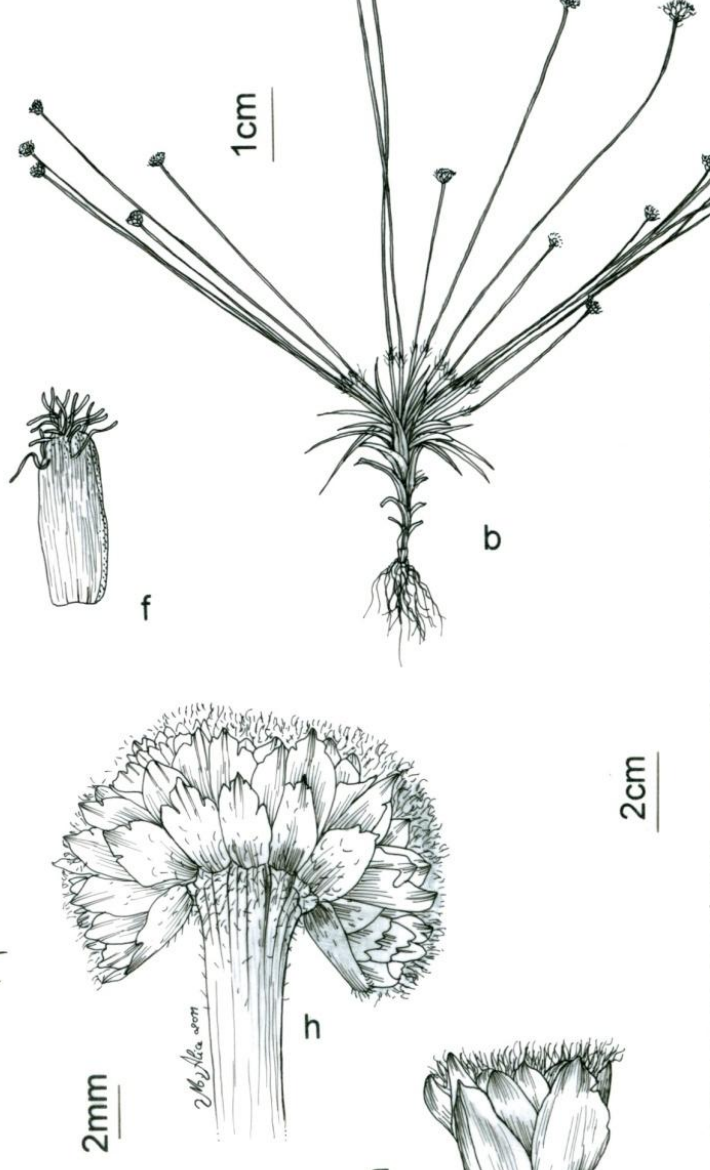

$\mathrm{h}$

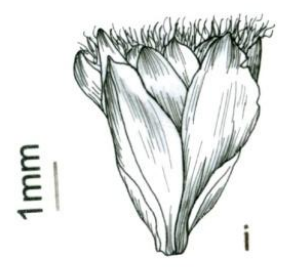

g

Fig. 4. a. Paepalanthus macaheensis: a. hábito. b-c. P. manicatus: b. hábito; c. face adaxial da folha. d-f. P. miser: d. hábito; e. capítulo; f. face abaxial da bráctea floral. g-i. P. planifolius: g. face abaxial da folha; h. inflorescência composta; i. Capítulo isolado (a Forzza 3957; b-c Forzza 3282; d-f Sarquis 2; g-i Forzza 3138). 
involucrais nunca superando o capítulo, castanhas, dispostas em 2 séries, obovais, puberulentas, margem vilosa, ápice cuspidado. Flores 3-meras. Brácteas florais com margens enegrecidas, oblanceoladas, glabras, margem vilosa, ápice obtuso. Flores estaminadas ca. 2,1 $\mathrm{mm}$ compr., sésseis; sépalas castanhas, lanceoladas, vilosas, ápice agudo; tubo da corola hialino; anteras creme; pistilódios 3, papilosos. Flores pistiladas ca. $2 \mathrm{~mm}$ compr.; sépalas alvas com ápice enegrecido, glabras, margem ciliada, ápice acuminado; pétalas hialinas, oblongas, ápice obtuso, densamente hirsuto; ramos estigmáticos bífidos, do mesmo tamanho dos ramos nectaríferos.

Material examinado: s.I., 24, IX, 1976, L. Krieger s.n. (CESJ 14312, RB, SPF); Gruta do Cruzeiro, 20.I.2005, $R$. C. Forzza et al. 3957 (RB).

Paepalanthus macaheensis era conhecida apenas para a região de Macaé de Cima, sendo aqui registrada pela primeira vez para Minas Gerais. No PEIB forma grande população apenas na Gruta do Cruzeiro, ocorrendo em solo arenoso na borda de mata nebular. É distinta das demais espécies ocorrentes no Parque pelo longo caule aéreo portando folhas lanceoladas.

4.13. Paepalanthus manicatus Pouls. ex Malme, Bih. Vet. Akad. 27(11): 28. 1901.

Fig.4. B-C.

Planta 4,5-8,5 cm alt. Rizoma ausente. Caule aéreo 0,3-1,2 cm compr. Folhas dispostas ao longo do caule, lineares 8-12 X 0,3-0,5 mm, setosas, ápice agudo. Espatas 6-8 mm compr., glabras, fendidas obliquamente, não estriadas, ápice dilatado. Escapos 1,6-3,8 cm compr., seríceos, tricostados, livres. Capítulos semiglobosos, 2-4 $\mathrm{mm}$ diâm., não vivíparos; brácteas involucrais nunca superando o capítulo, pardas, dispostas em 3 séries, lanceoladas, glabras, margem ciliada, ápice agudo. Flores 3-meras. Brácteas florais pardas, lanceoladas, glabras, margem vilosa, ápice agudo. Flores estaminadas ca. $2 \mathrm{~mm}$ compr.; pedicelo ca. $1 \mathrm{~mm}$ compr., glabro; sépalas castanhas, obovais, glabras, margem setosa, ápice obtuso; tubo da corola hialino; anteras alvas; pistilódios 3, papilosos. Flores pistiladas ca. 1,8 mm compr.; sépalas castanhas, obovais, glabras, margem velutina, ápice agudo; pétalas hialinas, lineares, glabras, margem serícea, ápice agudo; ramos estigmáticos bífidos, maiores que os ramos nectaríferos.

Material examinado: s.l., 6.III.2006, F.R.G. Salimena et al. 1307 (CESJ); Cachoeirinha, 31.III.2004, C. Morato et al. 22 (RB); entre a Ponte de Pedra e o Camping, 30.III.2004, R.C. Forzza et al. 3282 (RB, SPF).

Paepalanthus manicatus apresenta ampla distribuição no Brasil, ocorrendo no PEIB em solo arenoso úmido. É distinta das demais espécies do Parque por possuir pequeno porte, folhas dispostas ao longo do caule e escapos delgados.
4.14. Paepalanthus miser Ruhland in Engl., Pflanzenr. 4: 133. 1903.

Fig.4. D-F.

Planta ca. $5 \mathrm{~cm}$ alt. Rizoma ausente. Caule aéreo ca. $5 \mathrm{~mm}$ compr. Folhas dispostas em roseta, lineares, 8-2 X 0,5-1 mm, glabras, ápice agudo. Espata ca. $1 \mathrm{~cm}$ compr., glabra, fendida obliquamente, não estriada, ápice não dilatado. Escapos $5,5 \mathrm{~cm}$ compr., glabros, tricostados, livres. Capítulo semigloboso, $4 \mathrm{~mm}$ diâm., não vivíparos; brácteas involucrais nunca superando o capítulo, castanhas, em 3 séries, elípticas, glabras, ciliadas, ápice obtuso. Flores 3-meras. Brácteas florais castanho-escuras, oblongas, glabras, ciliadas, ápice agudo. Flores estaminadas ca. $2 \mathrm{~mm}$ compr.; pedicelo ca. 0,5 mm compr., com longos tricomas; anteras creme; sépalas castanho-escuras, obovais, glabras, ciliadas, ápice agudo; tubo da corola hialino; pistilódios 3, papilosos. Flores pistiladas ca. $2 \mathrm{~mm}$ compr.; sépalas castanho-escuras, obovais, glabras, ciliadas, ápice obtuso; pétalas hialinas, elípticas, glabras, ciliadas, ápice agudo; ramos estigmáticos bífidos, com o dobro do tamanho dos ramos nectaríferos.

Material selecionado: s.I., VI.1896, H. Magalhães 1370 (B, holótipo); s.I., V.1970, U.C. Câmara s.n. (CESJ 9155, RB, SPF); s.I., 3.XI.1973, U.C. Câmara 157 (CESJ, RB, SPF); Pico do Pião, 27.IX.1970, P.I.S. Braga 1871 (RB); mata da Gruta dos Três Arcos, 11.VIII.2005, R.C. Forzza et al. 4149 (RB); Gruta do Monjolinho, 19.IX.2006, R.C. Forzza et al. 4253 (RB); idem, 18.IX.2007, C. Sarquis et al. 2 (RB, SPF); Janela do Céu, 20.IX.2006, R.C.Forzza et al. 4258 (K, $\mathrm{RB}, \mathrm{SPF}$ ); entre a Mata Grande e a Ponte de Pedra, 30.III.2004, R. C. Forzza et al. 3281 (RB).

Paepalanthus miser é endêmica do PEIB, onde ocorre em locais úmidos e sombreados, especialmente no interior de grutas. Semelhante a $P$. freyreissii, pode ser distinguida pela cor das brácteas involucrais e pelo hábito grácil.

4.15. Paepalanthus planifolius (Bong.) Körn. in Mart. \& Eichler, Fl. bras. 3(1): 413. 1863.

Fig.4. G-I.

Planta ca. $63 \mathrm{~cm}$ alt. Rizoma ausente. Caule aéreo ca. 2,4 cm compr. Folhas dispostas em roseta, lanceoladas, $16-27,5 \times 0,8-2 \mathrm{~cm}$, pilosa na face abaxial, ciliadas, ápice agudo. Espatas 15-18,5 cm compr., truncadas, esparsamente pilosas, não estriadas, ápice não dilatado. Escapos 36-61 cm compr., glabros, multicostados, unidos. Capítulos urceolados, 3-4 mm diâm., não vivíparos; brácteas involucrais nunca superando o capítulo, castanho-esverdeadas, dispostas em 2-4 séries, obovais, ciliadas, ápice agudo. Flores 3meras. Brácteas florais castanhas, obovais, pilosas no ápice agudo. Flores estaminadas ca. $3 \mathrm{~mm}$, pedicelo ca. $1 \mathrm{~mm}$, com longos tricomas; sépalas castanhas, lanceoladas, pilosas na face abaxial e no ápice agudo; tubo da corola hialino, anteras alvas, pistilódios 3, papilosos. Flores pistiladas ca. $2 \mathrm{~mm}$ compr.; sépalas castanhas, lanceoladas, pilosas na face abaxial, ápice agudo; pétalas castanho-hialinas, obovais, ápice obtuso, 


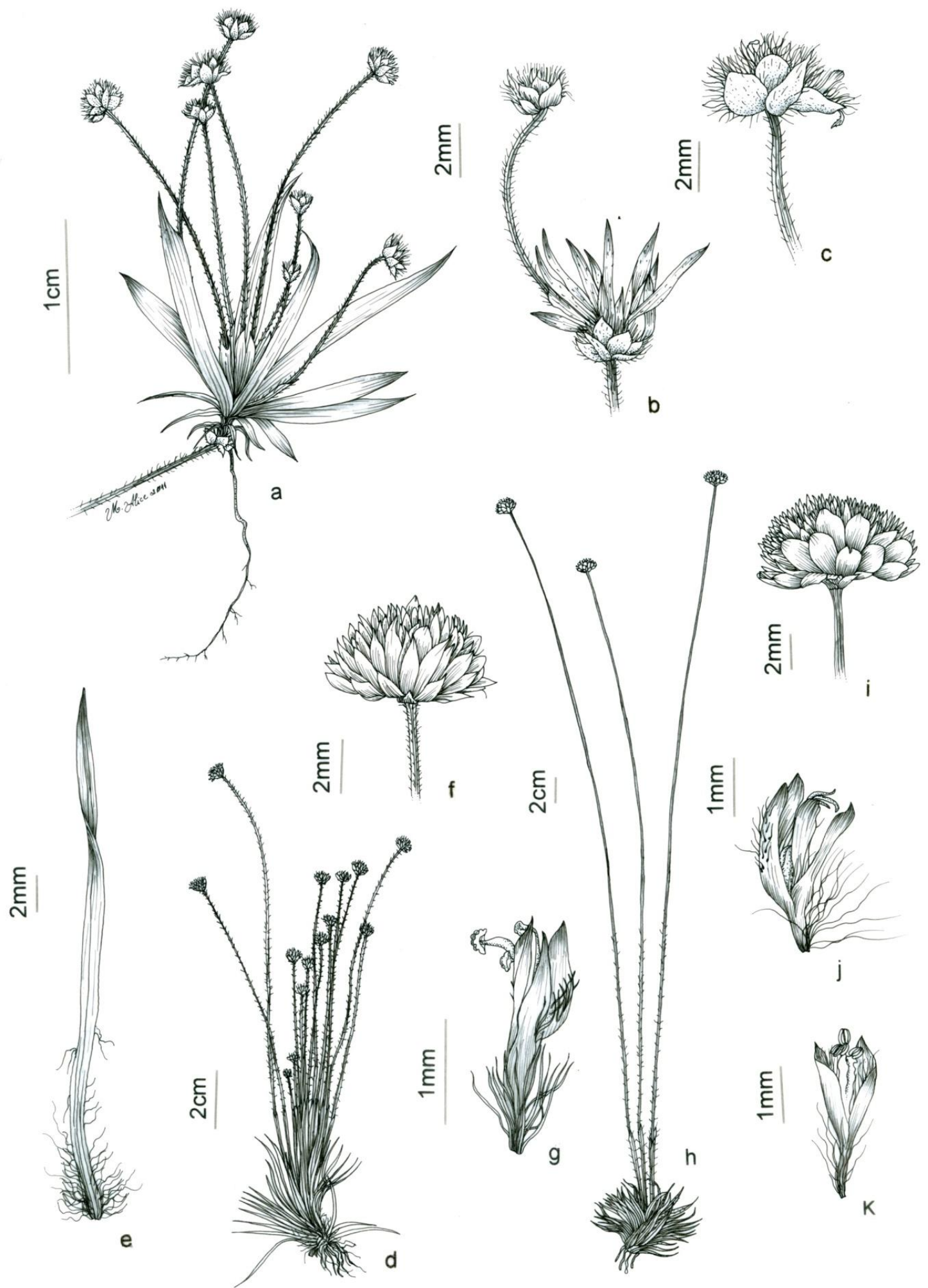

Fig. 5. a-c. Paepalanthus viridulus: a. hábito; b. capítulo vivíparo; c. capítulo. d-g. Syngonanthus costatus: d. hábito; e. face adaxial da folha; f. capítulo; g. flor estaminada. h-k. S. nitens: h. hábito; i. capítulo; j. flor pistilada; k. flor estaminada. (a, c Eiterer s.n. CESJ 24863; b Forzza 3538; d-g Krieger s.n. CESJ 14579; h-k Sarquis 5). 
pilosa; ramos estigmáticos bífidos, maiores do que os ramos nectaríferos.

Material selecionado: s.I., 3.XI.1973, U.C. Câmara 162 (BHCB n.v., CESJ 13288, MBM n.v., SPF) s.I., 16.VII.1977, L. Krieger S.n. (CESJ 15260, SPF); Monjolinho, 19.IX.1940, M. Magalhães 482 (SPF); Lago dos Espelhos, 15.VII.2005, M. L. O. Trovó et al. 184 (SPF); mata da Gruta dos Viajantes, 10.III.2004, R.C. Forzza et al. 3138 (K, NY, RB, SPF); Lago dos Espelhos, 18.IX.2007, C. Sarquis et al. 10 (RB, SPF).

Paepalanthus planifolius tem ampla distribuição no Brasil e, no PEIB, é encontrada nas margens de cursos d'água e lagos formando grandes populações. Suas folhas largas apresentam uma borda membranácea hialina que se estende da base até a região mediana, facilitando sua distinção. Assim como Paepalanthus dupatya, apresenta escapos unidos.

4.16. Paepalanthus viridulus Ruhland in Engl., Pflanzenr. 4-30: 165. 1903.

Fig.5. A-C.

Planta 2-4 cm alt. Rizoma ausente. Caule aéreo 3-8 mm compr. Folhas dispostas ao longo do caule ou

em roseta, lanceoladas, 1-2,3 X 1-3 mm, setosas, ápice acuminado. Espatas 3-5 mm compr., pilosas, fendidas obliquamente, não estriadas, ápice acuminado. Escapos 7-35 mm compr., hirsutos, tricostados, livres. Capítulos semiglobosos, 2-4 mm diâm., vivíparos; brácteas involucrais nunca superando o capítulo, douradas, dispostas em 2 séries, obovais, glabras, margem setosa, ápice agudo. Flores 3-meras. Brácteas florais amarelohialinas, obovais, glabras, margem setosa, ápice obtuso. Flores estaminadas ca. 1,5 mm compr.; pedicelo ca. 0,3 $\mathrm{mm}$ compr., com longos tricomas; sépalas amarelohialinas, oblanceoladas, glabras, margem velutina, ápice obtuso; tubo da corola amarelo-hialino; anteras creme; pistilódios 3, papilosos. Flores pistiladas ca. 1,5 mm compr.; sépalas amarelo-hialinas, obovais, glabras, margem setosa, ápice obtuso; pétalas hialinas, lineares, glabras, margem setosa, ápice agudo; ramos estigmáticos bífidos, maiores do que os ramos nectaríferos.

Material examinado: s.I., 15.V.1970, L.Krieger s.n. (CESJ 9184, RB); Pico do Pião, 15.V.1970, D. Sucre \& L. Krieger 6879 (RB, SPF n.v.); Gruta dos Três Arcos, 27.VII.1991, M. Eiterer et al. s.n. (CESJ 24863, RB, SPF); idem, 11.VIII.2005, R. C. Forzza et al. 4150 (RB); idem, 26.VII.2004, R. C. Forzza et al. 3538 (K, RB); idem, 19.IX.2007, C. Sarquis et al. 12 (RB, SPF); Janela do Céu, 20.IX.2006, R. C. Forzza et al. 4255 (RB); Ponte de Pedra, 8.V.2002, R. Marquete et al. 3219 (RB).

Paepalanthus viridulus é endêmica do PEIB, onde ocorre em locais úmidos e sombreados, em geral dentro de grutas. Assim como Paepalanthus cephalopus, apresenta capítulos vivíparos, porém pode ser diferenciada por possuir folhas mais longas e caule alongado.

\section{Syngonanthus Ruhland}

Ervas terrestres, perenes ou anuais. Folhas em roseta, lineares a cilíndricas, não fenestradas. Flores 3meras, sem glândulas nas pétalas, isostêmones. Brácteas florais ausentes. Flores estaminadas pediceladas, sépalas livre até a base, corola tubular, filetes livres ou adnatos à corola, anteras bitecas tetraesporangiadas, dorsifixas. Flores pistiladas sésseis, pétalas do mesmo tamanho que as sépalas, livres na base e no ápice, porém unidas na região mediana; ovário 3-locular, ramos estigmáticos simples; ramos nectaríferos inseridos no mesmo nível dos ramos estigmáticos.

Syngonanthus inclui cerca de 150 espécies com distribuição disjunta na África e Américas (Giulietti \& Hensold 1990, Giulietti et al. 2010). No PEIB são encontradas duas espécies.

5.1. Syngonanthus costatus Ruhland in Engl., Pflanzenr. 30-4: 252. 1903.

Fig.5. D-G.

Planta 3-18 cm alt. Rizoma ausente. Caule aéreo 0,3-1 cm. Folhas dispostas em roseta basal, lineares, 6-25 X 0,5-1 mm, pilosas, ápice acuminado. Espatas 0,6-3,4 cm, glabras, vilosas, fendidas obliquamente, não estriadas, ápice não-dilatado. Escapos 1,5-17,5 cm compr., hirsutos, tricostados, livres. Capítulos semiglobosos, 3-6 mm diâm., não vivíparos; brácteas involucrais nunca superando o capítulo, hialinas com base e centro dourados, dispostas em 2 séries, lanceoladas, glabras, ápice agudo. Flores 3-meras. Brácteas florais ausentes. Flores estaminadas ca. 2,5 $\mathrm{mm}$ compr., pedicelo ca. $1 \mathrm{~mm}$ compr., viloso; anteras alvas, sépalas hialinas, obovais, glabras, ápice obtuso, ciliado; tubo da corola hialino; pistilódios, 3, papilosos. Flores pistiladas ca. $2 \mathrm{~mm}$ compr.; sépalas hialinas, obovais, glabras, ápice obtuso, ciliado; pétalas hialinas, oblongas, pilosas, ápice truncado; Ramos estigmáticos simples, um pouco maiores do que os ramos nectaríferos.

Material selecionado: s.I., 28.IX.1970, U.C. Câmara s.n. (CESJ 9335, SPF); s.I., 25.II.1977, L. Krieger s.n. (CESJ 14579, SPF); subida para o Pião, 14.VII.2005, M.L.O. Trovó et al. 181 (SPF); Cascatinha, 11.III.2004, R.C. Forzza et al. 3218 (CESJ, K, RB, SPF); trilha Monjolinho - Lagoa Seca, 30.III.2004, C. Morato et al. 17 (RB); Cachoeirinha, 31.III.2004, C. Morato et al. 25 (K, RB, SPF); próximo ao Lago dos Espelhos, 18.IX.2007, C. Sarquis et al. 11 (RB, SPF).

Syngonanthus costatus é endêmica do PEIB, ocorrendo com grande frequência sobre rochas ou solo arenoso, sempre em ambientes úmidos, geralmente próximo a cursos d'água. Pode apresentar um ou mais escapos, cuja dimensão pode variar consideravelmente. 
5.2. Syngonanthus nitens (Bong.) Ruhland in Engl., Pflanzenr. 30 - 4: 254. 1903.

Fig.5. H-K.

Planta 29-36 cm compr. Rizoma ausente. Caule aéreo 1-4 $\mathrm{mm}$ compr. Folhas dispostas em roseta, lineares, 0,5-3,5 X 0,1-0,2 cm, glabrescentes, ápice agudo. Espatas 3-4,3 cm compr., pilosas, fendidas obliquamente, estriadas, ápice não dilatado. Escapos 27 $-37 \mathrm{~cm}$ compr., glabros, dourados, tricostados, livres. Capítulos semiglobosos 6-9 mm diâm., não vivíparos; brácteas involucrais nunca superando o capítulo, dourado-hialinas, dispostas em 3 séries, oblanceoladas, glabras, ápice obtuso. Flores 3-meras. Brácteas florais ausentes. Flores estaminadas ca. $3,5 \mathrm{~mm}$ compr.; pedicelo ca. $1 \mathrm{~mm}$ compr., viloso, anteras alvas, sépalas hialinas, oblanceoladas, pilosas, ápice obtuso; tubo da corola hialino, pistilódios 3, papilosos. Flores pistiladas ca. $4 \mathrm{~mm}$ compr., sépalas hialinas, lanceoladas, pilosas, ápice agudo; pétalas hialinas, lineares, glabras, ápice agudo; ramos estigmáticos simples, duas vezes maiores que os ramos nectaríferos.

Material examinado: s.I., 30.IX.1970, U.C. Câmara s.n. (CESJ 9409, MBM, SPF); s.I., 1.X.1970, L.Krieger \& U.C. Câmara s.n. (CESJ 9435, SPF); trilha entre Lago dos Espelhos e Monjolinho, 18.IX.2007, C. Sarquis et al. 5 (RB, SPF).

Syngonanthus nitens apresenta ampla distribuição na América. No PEIB é pouco frequente, ocorrendo em brejos e solos encharcados. É facilmente distinta das demais espécies pela coloração dourada do longo escapo.

\section{Agradecimentos}

Ao IEF-MG e à administração do Parque por todo apoio durante os trabalhos de campo. À dois revisores anônimos por suas valiosas sugestões. À Maria Alice Resende pelas belas e fidedignas ilustrações. Aos curadores dos herbários pelo empréstimo dos exemplares. À FAPERJ e FAPEMIG pelo auxilio financeiro. Ao $\mathrm{CNPq}$ pela bolsa de Iniciação Cientifica concedida a primeira autora (PIBIČ/JBRJ) e de Produtividade em Pesquisa concedida a terceira autora e a Alexander von Humboldt Foundation pela bolsa concedida ao segundo autor.

\section{Referências}

ANDRADE, P. \& SOUZA, H. 1995. Contribuição ao conhecimento da vegetação do Parque Estadual de Ibitipoca, Lima Duarte, Minas Gerais. Revista Árvore 19(2): 249-261.

ANDRADE, M.J.G., GIULIETTI, A.M., RAPINI, A., QUEIROZ, L.P., CONCEIÇÃO, A.S., ALMEIDA, P.R.M. \& VAN DEN BERG, C. 2010. A comprehensive molecular phylogenetic analysis of Eriocaulaceae: evidence from nuclear (ITS) and plastid (psbA-trnH and trnL-trnF) DNA sequences. Taxon 59: 379--388.
BORGES, R.A.X ; SAAVEDRA, M. ; NAKAJIMA, J.; FORZZA, R.C. 2010. The Asteraceae flora of the Serra do Ibitipoca: analyses of its diversity and distribution compared with selected areas in Brazilian mountain ranges. Systematics and Biodiversity 8: 471-479.

CETEC. 1983. Diagnóstico ambiental de Minas Gerais. CETEC. Belo Horizonte.

COSTA, C.M.R., HERRMANN, G., MARTINS, C.S., LINS, L.V. \& LAMAS, I.R. (orgs.) 1998. Biodiversidade em Minas Gerais: um atlas para sua conservação. Fundação Biodiversitas. Belo Horizonte.

DRUMMOND, G.M., MARTINS, C.S., MACHADO, A.B.M., SEBIO, F.A. \& ANTONINI, Y. (eds.) 2005. Biodiversidade em Minas Gerais: um atlas para a sua conservação. Fundação Biodiversitas. Belo Horizonte.

FERREIRA, F. M. ; COSTA, A.F.; FORZZA, R.C. 2009. Bambusoideae (Poaceae) no Parque Estadual de Ibitipoca, Minas Gerais Brasil. Bol. Bot. Univ. São Paulo 27: 203-218.

FONT QUER, P. 1989. Diccionario de Botânica. Editorial Labor. Barcelona.

FONTES, M. A. 1997. Análise da composição florística das florestas nebulares do Parque Estadual do Ibitipoca, Minas Gerais. Dissertação de Mestrado. Universidade Federal de Lavras, Lavras.

GIULIETTI, A.M. 1984. Estudos taxonômicos no gênero Leiothrix Ruhl. (Eriocaulaceae). Tese de LivreDocência. Inst. Bioc. Univ. S. Paulo. São Paulo.

GIULIETTI, A.M. 1996. Leiothrix Ruhland (Eriocaulaceae) no estado da Bahia, Brasil. Sitientibus Série Ciências Biológicas 15: 61-82.

GIULIETTI, A.M. \& HENSOLD, N. 1987. Eriocaulaceae In A.M. Giulietti, N.L. Menezes, J.R. Pirani, M. Meguro \& M.G.L. Wanderley - Flora da Serra do Cipó, Minas Gerais: caracterização e lista das espécies. Bol. Bot. Univ. São Paulo 9: 112-116

GIULIETTI, A.M. \& HENSOLD, N. 1990. Padrões de distribuição geográfica dos gêneros de Eriocaulaceae. Acta Bot. Bras. 4 (1): 133-158.

GIULIETTI, A.M. \& PARRA, L. R. 1995. Eriocaulaceae In B.L. Stannard (ed) Flora of the Pico das Almas, Chapada Diamantina, Bahia, Brasil. The Royal Botanical Gardens. Kew, p. 684-704.

GIULIETTI, A.M., SCATENA, V.L., SANO, P.T., PARRA, L.R., QUEIROZ, L.P., HARLEY, R.M., MENEZES, N.L., YSEPON, A.M.B., SALATINO, A., SALATINO, M.L., VILEGAS, W., SANTOS, L.C., RICCI, C.V., BONFIM, M.C.P. \& MIRANDA, E.B. 2000. Multidisciplinary studies on Neotropical Eriocaulaceae In K.L. Wilson \& D.A. Morrison (eds) Monocots: Systematic and Evolution. CSIRO Publishing. Melbourne, p. 580-589.

GIULIETTI, A.M., PARRA, L.R. \& SANO, P.T. 2003. Eriocaulaceae In D.C. Zappi, E. Lucas, B.L. Stannard, E.N. Lughadha, J.R. Pirani, L.P. Queiroz, S. Atkins, D.J.N. Hind, A.M. Giulietti, R.M. Harley \& A.M. Carvalho - Lista das plantas vasculares de Catolés, Chapada Diamantina, Bahia, Brasil. Bol. Bot. Univ. São Paulo 21(2): 393-395.

GIULIETTI, A.M., HARLEY, R.M., QUEIROZ, L.P., WANDERLEY, M.G.L. \& VAN DEN BERG, C. 2005. Biodiversidade e conservação das plantas no Brasil. Megadiversidade 1: 52-61. 
GIULIETTI, A.M., SANO, P.T., COSTA, F.N., PARRA, L.R., ECHTERNACHT, L., TISSOT-SQUALLI M.L., TROVÓ, M., WATANABE, M.T.C., FREITAS, M.P. \& HENSOLD, N. 2010. Eriocaulaceae. In R.C. Forzza, J.F. Baumgratz, C.E.M. Bicudo, J.A. Carvalho, A. Costa, D.P. Costa, M.J.G. Hopkins, P. Leitman, L.G. Lohmann, L.C. Maia, G. Martinelli, M. Menezes, M.P. Morim, M.N. Coelho, A.L. Peixoto, J.R. Pirani, J. Prado, L.P. Queiroz, V.C. Souza, J.R. Stehmann, L. Sylvestre, B.M.T. Walter \& D. Zappi (eds). Catálogo de plantas e fungos do Brasil. Rio de Janeiro: Jardim Botânico do Rio de Janeiro, vol. 2, p. 938-958.

HARLEY, R. M. \& SIMMONS, N. A. 1986. Flórula de Mucugê: Chapada Diamantina-Bahia, Brazil. Royal Botanic Gardens. Kew.

KOERNICKE, F. 1863. Eriocaulaceae. In C.P.F. Martius \& A.G. Eichler (eds.) Flora brasiliensis. Frid. Fleischer. Leipzig, vol.3, pars 1, p. 273-307, tab. 38-63.

MENINI NETO, L.; ALVES, R. J. V; BARROS, F. \& FORZZA, R. C. 2007a. Orchidaceae do Parque Estadual de Ibitipoca, MG, Brasil. Acta Bot. Bras. 21(3): 687-696.

MENINI NETO, L.; ALVES, R. J. V. \& FORZZA, R. C. 2007b. A subtribo Pleurothallidinae (Orchidaceae) no Parque Estadual de Ibitipoca, Minas Gerais - Brasil. Bol. Bot. Uni. São Paulo 25(2): 253-278.

MIRANDA, E.B. \& GIULIETTI, A.M. 2001. Eriocaulaceae no Morro do Pai Inácio (Palmeiras) e Serra da Chapadinha (Lençóis), Chapada Diamantina, Bahia, Brasil. Sitientibus Série Ciências Biológicas 1 (1): 1532.

PARRA, L.R.; GIULIETTI, A.M.; ANDRADE, M.J.G. \& VAN DEN BERG, C. 2010. Restablishment and new circumscription of Comanthera (Eriocaulaceae). Taxon 59(4): 1135-1146.

RADFORD, A.E, DICKISON, W.C., MASSEY, J.R., BELL, C.R. 1976. Vascular plant systematics. Harper and Row. New York, p. 89-200.

RODELA, L.C. 1998. Cerrados de altitude e campos rupestres do Parque Estadual de Ibitipoca, sudeste de Minas Gerais: distribuição e florística por subfisionomias da vegetação. Revta Depart. Geografia USP 12: 163-189.

RUHLAND, W. 1903. Eriocaulaceae. In A. Engler (ed.) Das Pflanzenreich. Wilhelm Engelmann. Leipzig, vol. IV-30, p. 1-294.

SALIMENA, F.R.G. 2000. Ecoturismo x conservação dos campos rupestres. In Tópicos atuais em botânica: Palestras convidadas do $51^{\circ}$ Congresso Nacional de Botânica. Brasília, p. 343-347.

SANO, P.T., GIULIETTI, A.M., TROVÓ, M., PARRA, L.R. \& MÜLLER, G. 2010. Flora de Grão-Mogol, Minas Gerais: Eriocaulaceae. Bol. Bot. Univ. São Paulo 28: 125-140.

SILVEIRA, A.A. 1908. Flora e serras mineiras. Imprensa Official. Belo Horizonte.

SILVEIRA, A.A. 1928. Floralia montium. Imprensa Official. Belo Horizonte, vol 1.

STÜTZEL, T. 1998. Eriocaulaceae In K. Kubitzki (ed.) The families and genera of vascular plants, vol. IV: Flowering Plants Monocotyledons - Alismatanae and Commelinanae (except Gramminae). Springer Verlag. Berlin, p. 197-207.
TROVÓ, M., SANO, P.T. 2010. Nomenclatural and taxonomic changes in Paepalanthus (Eriocaulaceae) from São Paulo e Minas Gerais, Brazil. Kew Bull. 65: 275-278.

\section{Lista de exsicatas}

Os números entre parênteses correspondem à numeração das espécies no texto.

Andrade, P. M. 926 (4.5), 967 (5.1), 1034 (4.5), 1040 (4.15), 1114 (4.5), 1133 (4.5), 1164 (4.5). Araújo, F. S. 7 (4.5), 31 (4.15). Bezerra, L. M. 82 (4.9). Braga, P.I.S. 1871 (4.14), 1918 (4.9). Brügger, M. 1759 (4.7). Câmara, U.C. 152 (4.9), 153 (4.5), 154 (1.1), 157 (4.14), 158 (3.1), 159 (1.2), 160 (4.8), 161 (1.2), 162 (4.15); Câmara, U.C. s.n. CESJ 9155 (4.14), 9335 (5.1), 9406 (3.1), 9409 (5.2), 9410 (4.1), 9411 (4.9), 9434 (4.15), 9434B (4.10) 9436 (4.8), 13275 (4.10), 13276 (4.1), 13280 (4.2), 13282 (4.15), 13288 (4.15), 13629 (1.1). Coons, M.P. 305 (5.1), 306 (4.7), 333 (4.1), 361 (4.14). Dias-Melo, R. 205 (4.1). Eiterer, M. 81 (1.2), 82 (4.7); Eiterer, M. s.n. CESJ 24860 (1.2), 24863 (4.16), 24865 (5.1), 24866 (4.4), 24876 (4.5), 24877 (5.1), 24878 (4.5), 24898 (4.5). Ferreira, F.M. 1015 (5.1), 1046 (4.8), 1101 (4.1). Forzza, R.C. 1794 (1.2), 1835 (1.2), 1842 (4.10), 3090 (4.7), 3091 (4.7), 3100 (4.5), 3138 (4.15), 3218 (5.1), 3241 (4.9), 3280 (4.9), 3281 (4.14), 3282 (4.13), 3538 (4.16), 3539 (4.14), 3578 (3.1), 3957 (4.12), 4221 (4.8), 4149 (4.14), 4150 (4.16), 4251 (4.9), 4253 (4.14), 4255 (4.16), 4258 (4.14), 4265 (1.1). Heluey, M.A. 19 (5.1), 26 (5.1), 27 (4.7), 51(3.1), 77 (4.7), 78 (5.1), 97 (5.1), 100 (4.5), 111 (4.15), 119 (4.5), 123 (4.15), 145 (3.1), 146 (4.5). Krieger, L. S.n. CESJ 8665 (1.1), 8747 (4.15), 9147 (4.9), 9158 (5.1), 9159 (4.7), 9161 (4.9), 9164 (4.5), 9184 (4.16), 9257 (4.14), 9300 (4.14), 9344 (4.9), 9372 (3.1), 9373 (4.1), 9435 (5.2), 9452 (4.5), 14312 (4.12), 14536 (4.7), 14541 (5.1), 14579 (5.1), 14584 (4.1), 14595 (1.1), 14600 (5.1), 14614 (4.5),14615 (4.5), 15245 (4.8), 15250 (4.15) (3.1), 15257(1.1), 15258 (5.1), 15260 (4.15), 15266 (4.9), 16577 (4.9), 16582 (4.5), 35539 (1.1). Monguilhott, L. 116 (4.9), 137 (1.2), 138 (5.1), 145 (4.9). Magalhães, H. 1374 (4.3),1654 (4.6), 2915 (4.11). Magalhães, M. 433 (4.5), 482 (4.15), 483 (2.1). Marquete, R. 3117 (4.8), 3219 (4.16). Martinelli, G. 15268 (4.1). Medeiros, E.V.S. 302 (4.14), 345 (1.1). Morato, C. 16 (4.10), 17 (5.1), 18 (4.7), 19 (4.9), 20 (1.2), 21 (4.5), 22 (4.13), 23 (1.1), 25 (5.1), 26 (5.1). Pires, F.R.S. s.n. CESJ 24770A (3.1), 24770B (4.5). Rodela, L.G. s.n. CESJ 29025 (4.5). Salimena, F.R. 1307 (4.13), 1329 (4.5). Santos, M.F. 42 (4.9), 46 (4.8), 47 (4.9), 49 (1.1). Sarquis, C. 1 (4.9), 2 (4.14), 3 (4.10), 4 (3.1), 5 (5.2), 6 (4.5), 7 (4.2), 8 (4.8), , (4.8), 10 (4.15), 11 (5.1), 12 (4.16), 13 (4.4), 14 (3.1), 15 (1.2), 16 (1.1). Silva, B.R. $1272(1.2), 1275$ (4.7). Sousa, H. S. s.n. BHCB 10918 (4.5). Sucre, D. 6879 (4.16), 6793 (4.1), 7236 (1.1). Trovó, M. 172 (4.5), 176 (4.8), 177 (4.8), 181 (5.1), 184 (4.15), 192 (4.2). Valente, A. 40 (1.1), 158, 173 (4.1). Verardo, S.M.S. s.n. CESJ 25361 (4.14), 25362 (4.8). 